\title{
Flux estimation, temporal trends and source determination of trace metal contamination in a major tributary of the Seine estuary, France
}

\author{
Gardes Thomas 1, 2, ", Debret Maxime ${ }^{1}$, Copard Yoann ${ }^{1}$, Coynel Alexandra ${ }^{3}$, Deloffre Julien ${ }^{1}$, \\ Fournier Matthieu ${ }^{1}$, Revillon Sidonie ${ }^{4}$, Nizou Jean ${ }^{4}$, Develle Anne-Lise ${ }^{5}$, Sabatier Pierre ${ }^{5}$, \\ Marcotte Stéphane ${ }^{6}$, Patault Edouard ${ }^{1}$, Faivre Quentin ${ }^{7}$, Portet-Koltalo Florence ${ }^{2}$
}

1 Normandie Univ, Rouen, UNIROUEN, UNICAEN, CNRS, M2C, 76000 Rouen, France

2 Normandie Univ., Rouen, UMR CNRS, 6014 COBRA, 55 Rue Saint Germain, 27000 Evreux, France

3 Université de Bordeaux, UMR EPOC CNRS 5085, 33615 Pessac, France

4 IFREMER, IUEM, Place N. Copernic, F-29280 Brest, France

5 Université Grenoble Alpes, Université Savoie Mont Blanc, CNRS, EDYTEM, 73000 Chambéry, France

${ }^{6}$ Normandie Univ, Rouen, INSA de Rouen, UMR CNRS 6014 COBRA, Avenue de I'Université, 76801

Saint-Etienne-du-Rouvray Cedex, France

7 Université de Tours, EA 6293 GéHCO, Parc de Grandmont, 37200 Tours, France

* Corresponding author : Thomas Gardes, email address : thomas.gardes1@univ-rouen.fr

\begin{abstract}
:
Anthropogenic impacts on rivers have increased significantly over the past $\sim 150$ years, particularly at the beginning of the industrial revolution. Among other signs, this impact is manifested through the addition of trace metals and metalloid elements to rivers. The Eure River watershed in France covers an area of $6017 \mathrm{~km} 2$ and is a major tributary of the Seine estuary. It is not exempt from anthropogenic pressures and has been exposed to significant metal discharges over the last 80 years. The average concentrations of metals (i.e., $\mathrm{Cr}, \mathrm{Co}, \mathrm{Ni}, \mathrm{Cu}, \mathrm{Zn}, \mathrm{Ag}, \mathrm{Cd}, \mathrm{Sb}$, and $\mathrm{Pb}$ ), in suspended particulate matter currently transported by the river are high compared to the local geochemical background. Moreover, the lack of correlation between concentration variations and the hydrosedimentary behaviour of the Eure River suggests that the river is currently under anthropogenic pressure. Analysis of sediment cores indicate strong As contamination during the 1940s, Cr, Co, Ni, Cu, Zn, Ag, Cd, and $\mathrm{Hg}$ contamination during the 1960 s and 1970s, and $\mathrm{Sb}$ and $\mathrm{Pb}$ contamination during the 1990s and 2000s. The enrichment factors calculation suggests that total anthropogenic pressure within the Eure River watershed since the 1940s was comparable or higher than those in many other French watersheds. An estimation of particulate metal flux in 2017 shows that the Eure River watershed contributed to 7, 8, 9, 10 and 16\% of total inputs to the Seine estuary in $\mathrm{Cr}, \mathrm{Cu}, \mathrm{Zn}, \mathrm{Cd}$ and $\mathrm{Pb}$ respectively. Moreover, the estimation of past theoretical flux indicates that during the 1990s the Eure River watershed was the main contributor of particulate $\mathrm{Pb}$ to the estuary. The use of $\mathrm{Pb}$ isotopes has revealed that this contamination was primarily of industrial origin.
\end{abstract}




\section{Graphical abstract}

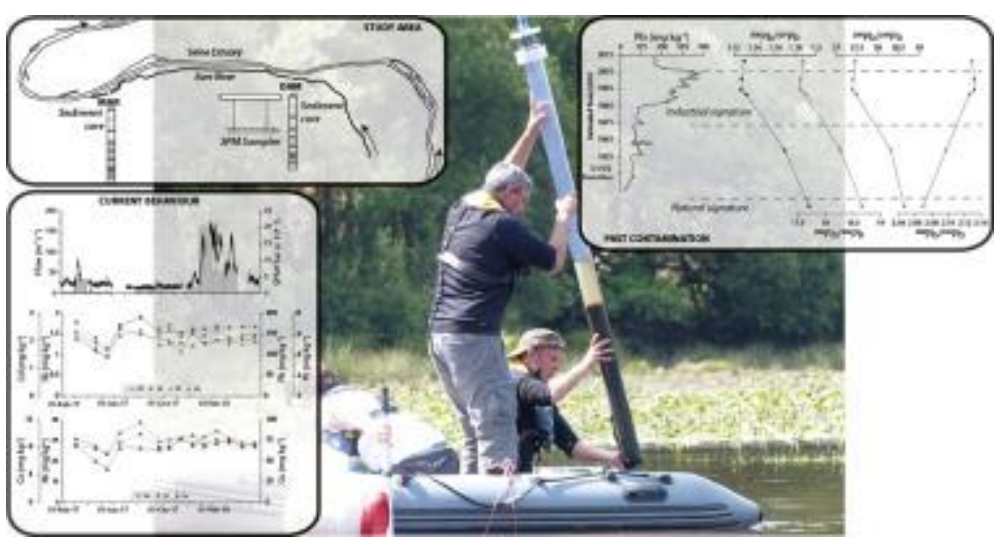

\section{Highlights}

- We assess and characterise the anthropogenic impacts occurring in the Eure River. Current particulate TMM concentrations and flux were estimated using TIMS. Temporal trends of TMM were reconstructed using sediment cores. A permanent anthropogenic baseline due to industrial contamination was highlighted. The origin of the $\mathrm{Pb}$ contamination can be traced using $\mathrm{Pb}$ isotopes.

Keywords : Anthropogenic impacts, Trace metals and metalloids, Eure River watershed, Temporal trends, Particulate metal flux, $\mathrm{Pb}$ isotopes 


\section{Introduction}

Trace metal and metalloid elements (TMM) are naturally present in rivers as a result of mechanical erosion processes or chemical alteration of uncontaminated rocks and soils. They also originate from multiple sources related to anthropogenic activities resulting in the contamination of rivers to varying degrees of severity (Salomons and Forstner, 1984). Anthropogenic impacts are sometimes very old and may date back to the Roman era (Elbaz- 
Poulichet et al., 2011), the Bronze Age (Elbaz-Poulichet et al., 2020), or even prehistory (Chiaradia et al., 2003). However, many studies agree that the impacts from the last 150 years, since the industrial revolution of western countries, have been much more significant (Foster and Charlesworth, 1996). Releases of TMM can be in dissolved and/or particulate form. Particulate discharges may be transported to the lower reaches of a watershed depending on hydraulic conditions, leading to the storage of these particles in accumulation areas within rivers, such as reservoirs behind dams, floodplains or ponds (Foster and Charlesworth, 1996). Using stored sediments, the reconstruction of temporal trends of metal contamination within a watershed is possible when the latter are undisturbed. Stored sediments with high accumulation rates (e.g., $\geq 1 \mathrm{~cm} \mathrm{y}^{-1}$ ) are only slightly affected by the early diagenesis process (Callender, 2000), thus these sediments can be used to trace temporal trends of metal contamination. This has been done for several large French rivers (e.g., Garonne River: Grousset et al., 1999; Audry et al., 2004; Seine River: Le Cloarec et al., 2011; Ayrault et al., 2012; Loire River: Grosbois et al., 2012; Dhivert et al., 2016).

The Eure River in Normandie, is a major tributary of the Seine estuary and is part of the Seine River watershed. This watershed is known for a history of significant metal contamination within its fluvial (Le Cloarec et al., 2011) and estuarine parts (Chiffoleau et al., 2012; Vrel, 2012).

The objective of this study is to assess and characterise the anthropogenic impacts within the Eure River watershed over the last 80 years. The quantification of current inputs from the Eure watershed into the Seine estuary was determined through TMM concentrations on suspended particulate matter (SPM), to enable determination of particulate metal flux. The reconstruction of TMM temporal trends was undertaken using sediment cores collected in the lower reaches of the watershed. The determination of natural values of TMM within the watershed allowed the assessment of current and past anthropogenic impacts. The magnitude 
of the impact could also be traced over time based on the estimation of past theoretical flux. The sources of the recorded contamination were determined by reconstructing the industrial history of the watershed and using $\mathrm{Pb}$ isotope ratios.

\section{Material and Methods}

2.1. Characteristics of the Eure watershed

The Eure River is a tributary of the Seine estuary, regulated upstream by the Poses Dam (Figure 1A). The Eure River watershed $\left(6,017 \mathrm{~km}^{2}\right)$ is the fourth largest tributary of the Seine River watershed in terms of surface area. It falls behind the Yonne, Marne and Oise watersheds but is the first contributing watershed in the estuarine section (i.e., the last $150 \mathrm{~km}$ before the mouth to the Channel). It is based on a chalk formation of the Upper Cretaceous, covered by Tertiary sandy-clay deposits and more recent deposits dating back to the Quaternary period (Quesnel, 1997; Laignel et al., 1998). The Eure River waters are characterised by a conductivity of $568 \pm 52 \mu \mathrm{S} \mathrm{cm}^{-1}$, a pH equal to $8.1 \pm 0.2$ and a mean temperature of $13 \pm 5{ }^{\circ} \mathrm{C}$ on the period from 1971 to 2019 (www.naiades.eaufrance.fr). Moreover, the Eure River has a mean annual flow $\left(\mathrm{Q}_{\text {mean }}\right)$ of $22.13 \pm 6.69 \mathrm{~m}^{3} \mathrm{~s}^{-1}$ based on the period from 1971 to 2019 (www.hydro.eaufrance.fr). It is the fifth largest tributary of the Seine watershed in terms of flow and its two major tributaries are the Avre and Iton rivers (Figure 1B).

\subsection{Field Sampling Methods}

\subsubsection{Description of core sites and sampling methodology}


Les Damps Pond is upstream of the Eure River spillway (Figure 1C). The pond, with an average depth of $50 \mathrm{~cm}$ and spanning an area less than 1 ha, continually accumulates SPM from the Eure watershed (Figure 1D). As the site is $2 \mathrm{~km}$ upstream of a spillway (vertical height: $\sim 3 \mathrm{~m}$ ), the tides have no noticeable effect, even in the case of a high tidal coefficient.

The Martot Pond, spanning an area of $\sim 7$ ha, is located in the lower reaches of the study area (Figure 1C). Unlike Les Damps Pond, this pond is affected by the Seine estuary during tidal flows through the Eure River outlet. However, the impact of the tide is limited and temporally variable, as its flow persists for about $3 \mathrm{~h}$ and does not occur every day. In addition, the Martot Dam, located 200 m downstream of the Martot Pond, prevented tidal flows for tidal coefficients lower than 70, until its removal in October 2017 (Figure 1E). Thus, to ensure Martot Pond was not impacted by the Seine River, results from this site were compared with those from Les Damps Pond. The Martot Dam also regulated the water level in the river, and the river was continuously connected to the Martot Pond, even during periods of low flow.

The La Forge Pond, located upstream of the Eure watershed, is crossed by the Avre River and is less than $10 \mathrm{~km}$ downstream of the headwaters of the Avre River (Figure 1F). This pond was constructed in anticipation of iron and steel activities during the seventeenth century. It is at the outlet of a watershed spanning less than $14 \mathrm{~km}^{2}$ where the geology is similar to that of the entire watershed, i.e., an Upper Cretaceous formation composed of flint clay (Turonian) and sand (Cenomanian) outcropping near the river.

Sediment cores were extracted using a UWITEC ${ }^{\circledR}$ gravity corer and PVC tubes with a diameter of $90 \mathrm{~mm}$ (e.g., Sabatier et al., 2014). The water-sediment interface was preserved during coring. Coring was carried out in the following dates and locations:

- January 2015 (DAM15-02 core) and January 2017 (DAM17-02 core) for Les Damps Pond; 
- January 2015 (MAR15-01 core) and February 2016 (MAR16-02 core) for Martot Pond; and

- June 2017 (FOR17-02 core) for La Forge Pond.

The characteristics of sediment cores are listed in Table 1.

\subsubsection{Measurement of flow and turbidity}

Streamflow of the Eure River $\left(\mathrm{Q}_{\text {water }} ; \mathrm{m}^{3} \mathrm{~s}^{-1}\right)$ was directly measured using an ArgonautSL3000 current meter (Side-Looking Doppler Current Meters; SonTeck®) installed on the left bank of the Eure River at the Les Damps site. Measurements were taken at 15 min intervals from 27 January 2017 to 22 May 2018 (Figure 1D).

Turbidity (NTU) was measured using a SAMBAT multi-parameter probe (with self-cleaning sensors; NKE Instrumentation $\left.{ }^{\circledR}\right)$ installed in the channel $90 \mathrm{~cm}$ below the surface at the Les Damps site. Measurements were taken at 15 min intervals during the same period as that of streamflow (Figure 1D).

\subsubsection{SPM sampling}

SPM were collected using an home-made time-integrated mass-flux sampler (TIMS), the design of which was based on Phillips et al. (2000) and Russell et al. (2000) (Figure S1 in supplementary materials). The central tube $(1 \mathrm{~m} \mathrm{long}$, diameter of $10 \mathrm{~cm})$ and the two outer inlet and outlet pieces are made of PVC. The pipe has a diameter of $4 \mathrm{~mm}$, allowing water to enter and exit, is made of nylon. The assembly of the parts and waterproofing of the central tube was undertaken using O-rings without glue. The TIMS were installed on a raft in the channel $90 \mathrm{~cm}$ below the surface at the Les Damps site, at the same depth as the turbidity sensor (Figure 1D). All TIMS changeover dates are shown in italics in Figure 2A.

\subsection{Analytical Methods and data processing}




\subsubsection{Grain size analysis}

Grain size distribution can influence the behaviour of chemical substances. Short-lived radionuclides $\left({ }^{210} \mathrm{~Pb},{ }^{137} \mathrm{Cs}\right.$, and $\left.{ }^{241} \mathrm{Am}\right)$ are preferentially adsorbed to fine particles (He and Walling, 1996) as metallic and metalloid elements (Salomons and Forstner, 1984; Horowitz and Elrick, 1987; Brügmann, 1995). Thus, grain size distribution can have a considerable impact on chronology and TMM concentrations in sediment cores (He and Walling, 1996).

The grain size distribution of sediment cores was measured by laser diffraction (LS 13320 Particle Size Analyser Beckman Coulter ${ }^{\mathrm{TM}}$ ) across a range 0.04-2000 $\mu \mathrm{m}$. Measurements occurred every $\mathrm{cm}$ by integrating $1 \mathrm{~cm}$ on the DAM15-02 and MAR15-01 cores.

\subsubsection{Total organic carbon analysis}

Total organic carbon (TOC) and the extent of organic matter (OM) degradation can influence TMM concentrations as some TMM have a strong affinity to TOC (Tseng et al., 2001; Audry et al., 2006; Masson et al., 2011; Petit et al., 2013; Coynel et al., 2016). As such, TOC contents are needed to determine whether variations in TMM in the sediment cores are related to anthropogenic activities.

Sediment Cores were analysed using Rock-Eval 6 (RE6) pyrolysis at the ISTO laboratory, University of Orléans ("Turbo" model RE6 pyrolyzer, Vinci Technologies), as per the method described in Copard et al. (2006). TOC and the OM quality were measured on the DAM17-02 and MAR15-01 cores at intervals of 2 and $1 \mathrm{~cm}$, respectively.

\subsubsection{XRF core scanning (XRF-CS)}

X-Ray fluorescence spectrometry (XRF) was used to semi-quantitatively determine the major and trace element variations of sediment deposits (Richter et al., 2006). The XRF core 
scanning data can be used to describe particulate TMM contamination in sediment cores (Lepland et al., 2010; Hennekam et al., 2019; Elbaz-Poulichet et al., 2020). The data presented were normalized by Ti to remove possible variations due to detrital inputs (Duan et al., 2014; Bábek et al., 2015). Ti was considered a better "normalizing element" than Al, which is used in coagulation/flocculation processes in wastewater treatment plants.

The relative contents of TMM were measured using an Avaatech XRF core scanner (EDYTEM, University of Savoie Mont Blanc). Measurements were taken every $5 \mathrm{~mm}$ for the MAR15-01 and DAM17-02 cores and every $2 \mathrm{~mm}$ for the MAR16-02 core.

\subsubsection{Particulate trace metal and metalloid analysis}

Microwave-assisted sediment digestion for particulate TMM analyses (for $\mathrm{As}, \mathrm{Cd}, \mathrm{Cu}, \mathrm{Cr}$, $\mathrm{Ni}, \mathrm{Mn}, \mathrm{Pb}, \mathrm{Zn}$ ), was performed on samples collected from the MAR16-02 and DAM17-02 cores. This consisted of $0.5 \mathrm{~g}$ of dry, powered and homogenised sediment with aqua regia $\left(\mathrm{HNO}_{3}: 3 \mathrm{~mL}\right.$ TraceMetal ${ }^{\mathrm{TM}}$ Grade; $\mathrm{HCl}: 9 \mathrm{~mL}$ TraceMetal $^{\mathrm{TM}}$ Grade, Fisher Scientific $\left.{ }^{\circledR}\right)$. Following pseudo-total mineralization (residual fractions containing silica particles being only partially digested), solutions were diluted in $100 \mathrm{~mL}$ Milli-Q ${ }^{\circledR}$ water. Particulate TMM concentrations were measured using inductively coupled plasma-atomic emission spectroscopy (ICP-AES, iCAP 6000 Series, Thermo Fischer ${ }^{\circledR}$ ) with external calibration. The accuracy and precision of measurements were verified with a certified reference material (Trace Element on Fresh Water Sediment CNS301-04-050, Sigma Aldrich) and results showed recoveries of $\geq 88 \%$ with a precision of $\sim 3.1 \%$.

Total digestions, including residual fractions, were performed on selected samples, collected at different depths for the DAM17-02 core, corresponding to the highest and lowest levels determined by ICP-AES. They were also conducted on sediment collected at the bottom of the FOR17-02 core. Representative samples consisting of $30 \mathrm{mg}$ of dry, powdered and 
homogenized sediment, were digested in closed polypropylene (PP) reactors (DigiTUBEs®, SCP SCIENCE) in a heating block $\left(2 \mathrm{~h}\right.$ at $\left.115{ }^{\circ} \mathrm{C}\right)$ with $1.5 \mathrm{ml} \mathrm{HCl}(12 M$ Suprapur®, Merck), $0.75 \mathrm{ml} \mathrm{HNO} 3$ (14 M Suprapur®, Merck) and $2.5 \mathrm{ml} \mathrm{HF}$ (22 M Suprapur ${ }^{\circledR}$, Merck), as described in previous studies (e.g., Coynel et al., 2016). Particulate TMM concentrations were measured by inductively coupled plasma-mass spectroscopy (ICP-MS, X7 Series 2, THERMO) with external calibration under standard conditions. The accuracy and precision of measurements were verified with certified reference materials (NCS DC 2702, CRM 8704, BCR 667) and results showed recoveries of $\geq 93 \%$ with a precision of $\leq 4 \%$ (relatively standard deviation; RSD). The concentrations (for $\mathrm{Cr}, \mathrm{Ni}, \mathrm{Cu}, \mathrm{Zn}, \mathrm{As}, \mathrm{Cd}$, and $\mathrm{Pb}$ ) determined by ICP-MS (total concentrations) were always consistent with those determined by ICP-AES (pseudo-total concentrations) being 1.1 to 1.5 times higher than the latter.

Sediment samples from MAR15-01 $(n=6)$ were analysed for $\mathrm{Pb}$ radiogenic isotopes. Reagents used for digestion and chemical procedures were prepared from sub-boiled distilled concentrated hydrochloric and nitric acids using a Cleanacids ${ }^{\circledR}$ device (Analab, France) except $\mathrm{HClO}_{4}$ (Suprapur®, Merck) Approximately $100 \mathrm{mg}$ of sample was weighed and dissolved in savillex ${ }^{\circledR}$ Teflon beakers in a mixture of HF (24 $M$, Cleanacids ${ }^{\circledR}$, Analab), $\mathrm{HNO}_{3}\left(14 M\right.$, Cleanacids ${ }^{\circ}$, Analab), and $\mathrm{HClO}_{4}(12 \mathrm{M}$, Suprapur®, Merck) for four days at $160{ }^{\circ} \mathrm{C}$ on a hot plate. After evaporation to dryness, samples were dissolved in aqua regia and heated for $24 \mathrm{~h}$ at $130{ }^{\circ} \mathrm{C}$. $\mathrm{Pb}$ fractions were chemically separated following conventional column chemistry procedures described in Gale (1996). Pb isotopic compositions analyses was conducted at the Pôle de Spectrométrie Océan (PSO) in Brest, France using a multicollector ICP-MS (MC-ICPMS, Neptune, Thermo Scientific). Pb isotope ratios were corrected for instrumental mass fractionation and machine bias using the Tl doping method of White et al. (2000) and SRM981 Pb standard bracketing for every three samples. Pb isotope reproducibility, based on 21 replicate analyses of NIST (National Institute of Standards and 
Technology) SRM981 was $0.0018(2 \sigma)$ for ${ }^{206} \mathrm{~Pb} /{ }^{204} \mathrm{~Pb}$ and ${ }^{207} \mathrm{~Pb} /{ }^{204} \mathrm{~Pb}$ and 0.0045 (2б) for ${ }^{208} \mathrm{~Pb} /{ }^{204} \mathrm{~Pb}$.

\subsubsection{Suspended particulate matter and particulate TMM flux determination}

To convert turbidity measurements into SPM concentrations $\left(\mathrm{C}_{\mathrm{MES}} ; \mathrm{mg} \mathrm{L}^{-1}\right)$, an NTU-SPM calibration line was established from SPM samples collected monthly at the Les Damps site (Figure S2). Equation (1) of this calibration line $\left(\mathrm{R}^{2}=0.85\right)$ is:

$C_{M E S}=1.155 \times$ Turbidity $\quad$ Equation (1)

The monthly SPM flux ( $\mathrm{F}_{\mathrm{SPM}} \mathrm{t}$ month $\left.^{-1}\right)$ was then determined according to Equation (2):

$F_{S P M}=\sum Q_{\text {water }} \times C_{M E S} \quad$ Equation (2)

Particulate TMM flux was estimated monthly over the sampling period based on the SPM flux and TMM concentrations determined from the collected SPM.

\subsubsection{Enrichment factors calculation}

To assess the impact of anthropogenic activities based on concentrations in environmental samples, these concentrations need to be standardised to reduce the influence of the sedimentary matrix (Ackermann, 1980; Daskalakis and O’Connor, 1995). Normalisation is based on a conservative trace element (i.e., not influenced by oxidation-reduction or diagenesis processes in sediments). Variations are characterised in the fine fraction varying proportionally with background concentrations, where most TMM are preferentially enriched. This normalising element should not have anthropogenic inputs that alter its distribution. The element Th is highly insoluble (Van Calsteren and Thomas, 2006), and is known to have a strong negative correlation with particle size, which allows its effects to be corrected (e.g., Coynel et al., 2007; Larrose et al., 2010; Lanceleur et al., 2011a, 2011b; Le Cloarec et al., 2011). In the literature, enrichment factors (EFs) are commonly used to estimate the impact 
of anthropogenic activities on the natural cycle of trace elements. EFs were determined according to Equation (3):

$$
E F=\frac{T E / R E}{T E_{\text {ref.background }} / T h_{\text {ref. background }}} \quad \text { Equation (3) }
$$

$T E$ and $R E$ represent the concentration of TMM studied and the reference element (Th) chosen for a given sample. $T E_{\text {ref. background }}$ and $R E_{\text {ref. background }}$ represent the natural content of the studied element and the natural content of Th, respectively.

\subsection{Core dating}

\subsubsection{Short-lived radionuclides}

The dating of recent deposits within sediment cores and the estimation of sedimentation rates was carried out using radioelements with short periods. The sedimentation rate was determined from the activity of ${ }^{210} \mathrm{~Pb}$ in excess $\left({ }^{210} \mathrm{~Pb}\right.$ ex $)$, by subtracting ${ }^{226} \mathrm{Ra}$ from the ${ }^{210} \mathrm{~Pb}_{\text {total }}$ (Goldberg, 1963). Artificial radioelements ${ }^{137} \mathrm{Cs}$ and ${ }^{241} \mathrm{Am}$ were used to identify nuclear weapons tests to confirm the age model established from the ${ }^{210} \mathrm{~Pb}_{\mathrm{ex}}$ results. A peak was observed in $1963 \mathrm{AD}$ and in $1986 \mathrm{AD}$ when the Chernobyl nuclear power plant accident occurred (Appleby et al., 1991).

The activities of ${ }^{210} \mathrm{~Pb}_{\mathrm{ex}},{ }^{137} \mathrm{Cs}$ and ${ }^{241} \mathrm{Am}$ were determined using gamma spectrometry with a germanium spectrometer in ultra-low background noise settings at the Laboratoire Souterrain de Modane (LSM). The age model was computed with serac $\mathrm{R}$ package (https://github.com/rosalieb/serac, (Bruel and Sabatier, 2020)). The MAR15-01 core was sampled from 0 to $80 \mathrm{~cm}$ at intervals of 2,4 , and $6 \mathrm{~cm}$.

\subsection{2. ${ }^{14}$ C dating}


${ }^{14} \mathrm{C}$ dating was conducted at the Poznań Radiocarbon Laboratory from organic macro remains collected at the bottom (i.e., $68-69.5 \mathrm{~cm}$ interval) of the FOR17-02 core. The IntCal13 calibration curve (Reimer et al., 2013) was used for ${ }^{14} \mathrm{C}$ age calibration, and the sample was determined to be from the period between 1646 and 1669 cal AD (Figure S3).

\section{Results and interpretation}

\subsection{Determination of local geochemical background}

The beginning of the FOR17-02 core $(68-69.5 \mathrm{~cm})$ was radiocarbon dated between 1646 and 1949 (1 sigma) with a maximum probability that it is between 1646-1669 (56\%) and 1781-1798 (39\%) (Figure S3). The 68-69.5 cm fraction was characterised by a median grain $\left(\mathrm{D}_{50}\right)$ of $20.9 \mu \mathrm{m}$ and a TOC content of $2.77 \%$ (dry weight; dw) (additional description of the FOR17-02 core is provided in Figure S4).

The TMM concentrations of this sample are summarized in Table 2. In light of the small geological variations within the Eure watershed and the sample being dated back to the preindustrial revolution period, the TMM concentrations are indicative of the geochemical background (GB) of the Eure watershed. The choice of the GB in this study, differs from some studies that have used levels measured at the bottom of sediment cores, considered representative of the GB (e.g., Gascón Díez et al., 2017), or used a regional geochemical baseline, representing levels measured prior to significant additional anthropogenic inputs, but not corresponding with a regional GB (Larrose et al., 2010). In other cases, for example for the Seine watershed $\left(67,500 \mathrm{~km}^{2}\right.$; Le Cloarec et al., 2011), the GB was the combination of several average levels of TMM in fine sediments collected in forest streams draining a single rock type (Horowitz et al., 1999; Thévenot et al., 2007). 


\subsection{Current behaviour of the Eure River}

\subsubsection{Hydro-sedimentary behaviour}

The average flow in the Eure River was $22.0 \mathrm{~m}^{3} \mathrm{~s}^{-1}$ at the Les Damps site in 2017. There were no major flood events during this year, with the exception of the month of March when streamflow reached $86.7 \mathrm{~m}^{3} \mathrm{~s}^{-1}$, the highest in 2017 . The beginning of 2018 was marked by a 50-year flood during which five flood peaks were recorded. Maximum flow values occurred between late January and early February 2018, with streamflows close to $180 \mathrm{~m}^{3} \mathrm{~s}^{-1}$ (Figure 2A).

The monthly SPM flux also followed the same trend as streamflow. The maximum monthly flux in 2017 was $4.27 \times 10^{4} \mathrm{t}$ in March 2017, while the minimum flux was $812 \mathrm{t}$ in July 2017 . The total flux for 2017 was $10.8 \times 10^{4} \mathrm{t}$, with a specific sediment yield (SSY) of about $18 \mathrm{t}$ $\mathrm{km}^{-2} \mathrm{y}^{-1}$. The 2018 flood (January-March) transported $36.0 \times 10^{4} \mathrm{t}$ of SPM, of which more than half $\left(20.4 \times 10^{4} \mathrm{t}\right)$ passed through in January (Figure $\left.2 \mathrm{~A}\right)$.

\subsubsection{Evolution of TMM concentrations}

Figure 2B presents the changes in TMM and Mn concentrations over the entire sampling period at the Les Damps site. According to the correlation matrix, most of the TMM and Mn did not show any correlation with $\mathrm{Q}_{\text {mean }}, \mathrm{SPM}_{\text {mean }}$ and dw (for SPM collected by TIMS), indicating that their concentration variations are not directly related to the hydro-sedimentary behaviour of the Eure River, nor to the mass of SPM collected (Figure S5). Only As showed positive but low correlations $(0.36<\mathrm{R}<0.56)$ with these three parameters. Overall, TMM and Mn were positively correlated with each other $(0.42<\mathrm{R}<0.99)$, but some elements such as $\mathrm{V}$, As and Th showed particularly strong positive correlations $(0.90<\mathrm{R}<0.99)$ and 
therefore co-variated during the sampling period. This was particularly the case during the 50year flood from 22 January to 19 February, 2018. During this time, only V, As and Th reached maximum levels at 55.3, 8.45 and $6.44 \mathrm{mg} \mathrm{kg}^{-1}$, respectively (Figure 2B). Chromium, $\mathrm{Co}, \mathrm{Ni}$ and $\mathrm{Mn}$ had strong correlations between them $(0.60<\mathrm{R}<0.89)$ and with $\mathrm{Th}$ or $\mathrm{V}$ for $\mathrm{Cr}$, Co and $\mathrm{Ni}(0.73<\mathrm{R}<0.88)$. Lead was correlated with $\mathrm{Ag}(\mathrm{R}=0.89)$ and $\mathrm{Sb}(\mathrm{R}=0.70)$, and like $\mathrm{Ag}$, was negatively correlated with $\mathrm{Q}_{\text {mean }}, \mathrm{SPM}_{\text {mean }}$ and $\mathrm{dw}$. This resulted in low levels of $\mathrm{Pb}$ and $\mathrm{Ag}$ during the flood with $\mathrm{Ag}$ having reached its lowest concentration of 0.75 $\mathrm{mg} \mathrm{kg}^{-1}$ (Figure 2B).

The average concentrations of V, As and Th based on the SPM were close to those of the GB of the Eure watershed (Table 2). The other TMM had average concentrations higher than those of the GB. Over the entire sampling period, $\mathrm{Cu}, \mathrm{Cd}$ and $\mathrm{Pb}$ measured at levels 12,18 , and 14 times higher than the GB, respectively.

For concentrations of TMM normalised by Th, the average ratios were found to be higher than those calculated for the GB, with the exception of V, As and Th. This indicates that the inputs of As within the watershed were not of anthropogenic origin. For the other TMM, it is likely that one or more additional anthropogenic sources releasing TMM into the river or that old contaminated and stored/trapped sediments/soils have been remobilised. This may be likely to occur during flood or work periods, and transit through the Eure River.

\subsubsection{Particulate TMM flux}

The total monthly flux of particulate TMM are listed in Table 3. In 2017, 50\% of TMM flux was transported between January and May as per the water flux. It may also have been transported between January and April for V, As, Ag, Cd, Sb and Th as per the SPM flux. Maximum flux occurred in March during the episodic flood. The flood in 2018 had a major impact on the transport of TMM within the watershed. Indeed, between January and March, 
the TMM flux was 3.3 times greater on average compared to the whole of 2017 . Note that this average ratio was 1.9 times if only the month of January is considered. Specifically, this behaviour was more pronounced for $\mathrm{V}, \mathrm{Co}, \mathrm{Ni}, \mathrm{Cu}, \mathrm{As}$, Th (ratio of 3.5-4.0) and less pronounced for $\mathrm{Ag}$ (ratio of 2.0) and $\mathrm{Pb}$ (ratio of 2.8). During the flood event, more than half $(57 \pm 1 \%)$ of the flux occurred in January, including the particulate flux for all the TMM. The TMM with the highest flux was $\mathrm{Zn}$ and $\mathrm{Pb}$, followed by $\mathrm{Cr}$ and $\mathrm{Cu}$ (Table 3).

While variations in TMM contents are independent of the hydro-sedimentary behaviour of the Eure River, variations in TMM flux, such as increases during flood periods, are due to the increase in hydro-sedimentary inputs. These streamflow increases are thus indicative of the increased erosion of soils or sediments stored in the river.

\subsection{Past contamination in the Eure River watershed}

\subsubsection{Sedimentary characteristics}

The sediment deposits of the DAM15-02 core (Les Damps Pond) had a grain size distribution mainly centred around $\mathrm{D}_{50}$, equal to $29.5 \pm 6.7 \mu \mathrm{m}$, with a constant TOC content of $5.36 \pm 0.47 \%$ (Figure 3A). The sediment deposits of the MAR15-01 core (Martot Pond), were characterised by two sedimentary facies called U2 $(77-138 \mathrm{~cm})$ and U1 $(0-77 \mathrm{~cm})$ (Figure 3B). Along U2, the grain size distribution was centred around a low $\mathrm{D}_{50}$ equal to 13.8 $\pm 7.0 \mu \mathrm{m}$, and there was a low and constant mean TOC content $(1.75 \pm 0.33 \%)$. Along U1, the grain size distribution was also centred around a $\mathrm{D}_{50}$ of $33.9 \pm 7.8 \mu \mathrm{m}$, and the mean TOC content $(3.88 \pm 1.49 \%)$ appeared to increase slightly within U1 towards the interface. There were particularly high values close to the interface (TOC $=8.26 \pm 0.19 \%$ between 9 and 12 $\mathrm{cm}$ ) (Figure 3B). The $\mathrm{D}_{50}$ and mean TOC content were higher in the Martot Pond for U1 compared to U2. However, the $\mathrm{D}_{50}$ of $\mathrm{U} 1$ in the Martot Pond and that of Les Damps Pond 
were comparable, while the mean TOC content was higher in Les Damps Pond (Gardes et al., 2020a).

\subsubsection{Age model}

The activity of ${ }^{210} \mathrm{~Pb}_{\mathrm{ex}}$ was measured up to $80 \mathrm{~cm}$ (U1 of MAR15-01 core) and was found to decrease almost continuously with depth (Figure 4A). A sedimentation rate of $12.73 \pm 2.2 \mathrm{~mm}$ $\mathrm{y}^{-1}\left(\mathrm{R}^{2}=0.60\right)$ was estimated using the 'constant flux, constant sedimentation rate' (CFCS) model (Krishnaswamy et al., 1971). The ${ }^{137} \mathrm{Cs}$ and ${ }^{241} \mathrm{Am}$ activities peaked at 60 and $58 \mathrm{~cm}$, respectively, corresponding to the maximum fallout from atmospheric nuclear weapon testing in 1963 (Robbins and Edgington, 1975). There was also a peak in the ${ }^{137}$ Cs activity at $40 \mathrm{~cm}$, potentially related to the Chernobyl accident in 1986 (Appleby et al., 1991) (Figure 4B). The first identification of ${ }^{137} \mathrm{Cs}$ activity dated 1955 (Pennington et al., 1973) corresponded to a depth of $71 \mathrm{~cm}$. From the mean sedimentation rate obtained by the ${ }^{210} \mathrm{~Pb}_{\mathrm{ex}}$, an age model was constructed that was consistent with the artificial radionuclide data (Figure 4C). The transition between U1 and U2 was dated at $1954 \pm 10 \mathrm{y}$. However, the history of the study site suggests that around 1939, the Martot Pond, then connected to the Seine River, was disconnected from the Seine River and subsequently connected to the Eure River in the following years. Thus, the U2 facies corresponds to sedimentary deposits from the Seine watershed while the U1 facies corresponds to contributions from the Eure watershed since the 1940s (Gardes et al., 2020a).

As the MAR16-02 and DAM17-02 cores on which the TMM were measured (see Section 3.3.3) were not dated, an age model was defined using the MAR15-01 core. This was done by linking the peaks of the $\mathrm{Pb} / \mathrm{Ti}$ and $\mathrm{Zn} / \mathrm{Ti}$ ratios together based on analogy, or using the U1/U2 transition level also visible along the MAR16-02 core (Figure S6). Among the several parameters useful to correlate sediment cores, XRF data is interesting because of the 
measurements resolution. In addition, $\mathrm{Pb}$ and $\mathrm{Zn}$ already showed distinct temporal trends in the Martot and Les Damps Ponds, using XRF analysed. Indeed, high levels of Zn were obtained in the 1950s-1960s whereas high levels of $\mathrm{Pb}$ were obtained in the 1990s, corresponding to the "middle" of the sediment cores and approximatively to the top of the sediment cores, respectively (Gardes et al., 2020a). The results indicated average sedimentation rates of $11.3 \mathrm{~mm} \mathrm{y}^{-1}$ for the MAR16-02 core and $12.2 \mathrm{~mm} \mathrm{y}^{-1}$ for the DAM1702 core.

\subsubsection{Evolution of the TMM concentrations along sediment cores}

- MAR16-02 core

The TMM concentrations in the MAR16-02 core were measured for U1 $(0-77 \mathrm{~cm})$, corresponding to inputs from the Eure River into the Martot Pond, and for the last length of U2 $(77-90 \mathrm{~cm})$, corresponding to inputs from the Seine River. Chromium, Mn, Ni, Cu, Zn and $\mathrm{Cd}$ concentrations increased from the transition U2/U1 (Seine Unit/Eure Unit) with a peak in the late 1950s $\left(\mathrm{Cr}=211 \pm 1 \mathrm{mg} \mathrm{kg}^{-1 ;} \mathrm{Mn}=2198 \pm 9 \mathrm{mg} \mathrm{kg}^{-1 ;} \mathrm{Ni}=48.9 \pm 0.1 \mathrm{mg} \mathrm{kg}^{-1}\right.$; $\left.\mathrm{Cu}=399 \pm 4 \mathrm{mg} \mathrm{kg}^{-1 ;} \mathrm{Zn}=905 \pm 1 \mathrm{mg} \mathrm{kg}^{-1 ;} \mathrm{Cd}=42.3 \pm 0.1 \mathrm{mg} \mathrm{kg}^{-1}\right)$, and in the mid-1950s for Mn. Levels of Cr, Mn, Ni, Zn, and Cd remained high until the early 1960s and then declined, in stages, until the late 1980s. From the 1980s onwards, the contents of Cr, Mn, Ni, $\mathrm{Cu}, \mathrm{Zn}$ and $\mathrm{Cd}$ remained stable $\left(\mathrm{Cr}=56.9 \pm 0.3 \mathrm{mg} \mathrm{kg}^{-1 ;} \mathrm{Mn}=234 \pm 1 \mathrm{mg} \mathrm{kg}^{-1 ;} \mathrm{Ni}=22.6 \pm\right.$ $0.1 \mathrm{mg} \mathrm{kg}^{-1 ;} \mathrm{Cu}=94.2 \pm 0.5 \mathrm{mg} \mathrm{kg}^{-1} ; \mathrm{Zn}=311 \pm 1 \mathrm{mg} \mathrm{kg}^{-1 ;} \mathrm{Cd}=3.78 \pm 0.03 \mathrm{mg} \mathrm{kg}^{-1}$ ) (Figure 5A). Arsenic concentrations had a peak in the U2 facies and then decreased during the transition from the Seine Unit to Eure Unit with a peak in the late $1950 \mathrm{~s}$ of $12.2 \pm 0.2 \mathrm{mg} \mathrm{kg}^{-1}$. Concentrations of As then decreased until the end of the 1980s, stabilising around a mean content of $4.12 \pm 0.23 \mathrm{mg} \mathrm{kg}^{-1}$ up to the surface (Figure $5 \mathrm{~A}$ ). Pb concentrations increased significantly from the late 1980 s with a peak of $669 \pm 3 \mathrm{mg} \mathrm{kg}^{-1}$ in the mid-2000s. During the 
2010s the $\mathrm{Pb}$ concentrations declined rapidly but remained elevated and above levels measured prior to the increase in the late 1980s (Figure 5A).

\section{- DAM17-02 core}

The evolution of TMM levels in the Les Damps Pond are similar to those obtained for the Martot Pond, indicating a global signature of the watershed within these two ponds, not impacted by local inputs (e.g., around the ponds). Indeed, the concentrations of $\mathrm{Cr}, \mathrm{Mn}, \mathrm{Ni}$, $\mathrm{Cu}, \mathrm{Zn}, \mathrm{Cd}$ were similar with the maxima during the 1960 s and $1970 \mathrm{~s}\left(\mathrm{Cr}=171 \pm 1 \mathrm{mg} \mathrm{kg}^{-1}\right.$; $\mathrm{Mn}=1283 \pm 2 \mathrm{mg} \mathrm{kg}^{-1} ; \mathrm{Ni}=75.4 \pm 0.2 \mathrm{mg} \mathrm{kg}^{-1} ; \mathrm{Cu}=490 \pm 1 \mathrm{mg} \mathrm{kg}^{-1} ; \mathrm{Zn}=992 \pm 3 \mathrm{mg} \mathrm{kg}^{-1} ;$

$\mathrm{Cd}=54.6 \pm 0.1 \mathrm{mg} \mathrm{kg}^{-1}$ ). This was followed by a decrease until the $1990 \mathrm{~s}$ before stabilising within the most recent deposits $\left(\mathrm{Cr}=39.0 \pm 0.9 \mathrm{mg} \mathrm{kg}^{-1} ; \mathrm{Mn}=140 \pm 1 \mathrm{mg} \mathrm{kg}^{-1} ; \mathrm{Ni}=17.0 \pm\right.$ $\left.0.1 \mathrm{mg} \mathrm{kg}{ }^{-1} ; \mathrm{Cu}=67.2 \pm 0.2 \mathrm{mg} \mathrm{kg}^{-1} ; \mathrm{Zn}=279 \pm 1 \mathrm{mg} \mathrm{kg}{ }^{-1} ; \mathrm{Cd}=3.34 \pm 0.02 \mathrm{mg} \mathrm{kg}^{-1}\right)$ (Figure 6). Chromium, $\mathrm{Mn}, \mathrm{Ni}, \mathrm{Cu}, \mathrm{Zn}$ and $\mathrm{Cd}$ share similar trends suggesting a common source for these TMM during the 1960s and 1970s. The maximum As concentration of $22.2 \pm$ $0.2 \mathrm{mg} \mathrm{kg}^{-1}$ was measured at the bottom of the DAM17-02 core around 1945. Levels then gradually decreased and stabilised at $5.26 \pm 0.14 \mathrm{mg} \mathrm{kg}^{-1}$ from the 1990s (Figure 6). $\mathrm{Pb}$ concentrations remained stable until the mid-1980s, then reached high concentrations during the $1990 \mathrm{~s}-2000$ with peaks of $854 \pm 8 \mathrm{mg} \mathrm{kg}^{-1}$ in the early $1990 \mathrm{~s}$. Pb concentrations then declined from the mid-2000s and reached concentrations close to those measured at the beginning of the record. However, these were still higher than the lowest concentrations obtained in the late 1960s (Figure 6).

3.4. Comparison between geochemical background values, past and current concentrations 
The total TMM concentrations measured by ICP-MS for the DAM17-02 core are also listed in Table 4. Vanadium and Th showed stable levels throughout the DAM17-02 core (V = 45.4 $\pm 5.4 \mathrm{mg} \mathrm{kg}^{-1}$ and $\mathrm{Th}=5.18 \pm 0.62 \mathrm{mg} \mathrm{kg}^{-1}$ ), these were close to the GB values of the Eure River ( $\mathrm{V}=43.2 \mathrm{mg} \mathrm{kg}^{-1}$ and $\mathrm{Th}=3.96 \mathrm{mg} \mathrm{kg}^{-1}$; Table 2$)$ and also close to the estimated levels for SPM (Figure 6). The temporal trends of $\mathrm{V}$ and $\mathrm{Th}$ confirm the absence of additional anthropogenic inputs within the watershed. Arsenic is the only TMM for which the lowest levels (corresponding to the most recent levels) were close to the GB value of $6.56 \mathrm{mg} \mathrm{kg}^{-1}$ (Table 2) and the levels measured on the SPM (Figure 6). The temporal trends in As confirm that there are no further anthropogenic additional inputs of As within the watershed. For the other TMM, the overall estimated concentrations in the DAM17-02 core were always higher than the GB values. Cobalt and $\mathrm{Ag}$ had similar trends to $\mathrm{Cr}, \mathrm{Mn}, \mathrm{Ni}, \mathrm{Cu}, \mathrm{Zn}$ or $\mathrm{Cd}$ and more precisely to $\mathrm{Cr}$ and $\mathrm{Zn}$ with a peak concentration in the 1970s (Figure 6). The most recent and oldest $\mathrm{Cr}, \mathrm{Co}, \mathrm{Ni}, \mathrm{Ag}$ and $\mathrm{Cd}$ concentrations in the DAM17-02 core were close to those measured on the SPM. In contrast, for $\mathrm{Cu}$ and $\mathrm{Zn}$, only the most recent concentrations were close to those measured on the SPM (Figure 6). Sb concentrations were similar to $\mathrm{Pb}$ with a peak concentration in the early 1990s of $6.62 \mathrm{mg} \mathrm{kg}^{-1}$. The Pb levels measured in the SPM were slightly lower than those measured for the most recent deposits in the DAM17-02 core.

For all the TMM, the small differences in value between the estimated concentrations in SPM and those measured in most recent sedimentary deposits show that sediment cores collected were representative of SPM transfers in the Eure River.

\subsection{Isotopic signature of $\mathrm{Pb}$ contamination}

For the Seine Unit, where the $\mathrm{Pb} / \mathrm{Ti}$ ratio was low (Figure S6), the values of the ${ }^{206} \mathrm{~Pb} /{ }^{207} \mathrm{~Pb}$, ${ }^{206} \mathrm{~Pb} /{ }^{204} \mathrm{~Pb}$ and ${ }^{208} \mathrm{~Pb} /{ }^{204} \mathrm{~Pb}$ ratios were higher than those recorded in the Eure Unit and lower 
for ${ }^{208} \mathrm{~Pb} /{ }^{206} \mathrm{~Pb}$. The $1990 \mathrm{~s}$ constituted a period of high $\mathrm{Pb}$ concentrations, where the ${ }^{206} \mathrm{~Pb} /{ }^{207} \mathrm{~Pb},{ }^{206} \mathrm{~Pb} /{ }^{204} \mathrm{~Pb},{ }^{208} \mathrm{~Pb} /{ }^{204} \mathrm{~Pb}$ ratios were low while the ${ }^{208} \mathrm{~Pb} /{ }^{206} \mathrm{~Pb}$ ratio was higher than the 1960s. This decrease in the ${ }^{206} \mathrm{~Pb} /{ }^{207} \mathrm{~Pb},{ }^{206} \mathrm{~Pb} /{ }^{204} \mathrm{~Pb},{ }^{208} \mathrm{~Pb} /{ }^{204} \mathrm{~Pb}$ ratios and increase in the ${ }^{208} \mathrm{~Pb} /{ }^{206} \mathrm{~Pb}$ ratio reflects a change in $\mathrm{Pb}$ source or inputs from a new source within the sediment record, contributing to the increased $\mathrm{Pb}$ levels. From the 2000s onwards, the ${ }^{206} \mathrm{~Pb} /{ }^{207} \mathrm{~Pb},{ }^{206} \mathrm{~Pb} /{ }^{204} \mathrm{~Pb}$ and ${ }^{208} \mathrm{~Pb} /{ }^{204} \mathrm{~Pb}$ ratios increased slightly and ${ }^{208} \mathrm{~Pb} /{ }^{206} \mathrm{~Pb}$ remained stable. This increase was confirmed for the ratios calculated in $2012 \pm 0.5 \mathrm{y}$ while the ${ }^{208} \mathrm{~Pb} /{ }^{206} \mathrm{~Pb}$ started to decrease (Figure 5B). This increase and decrease for ${ }^{208} \mathrm{~Pb} /{ }^{206} \mathrm{~Pb}$, corresponds to the decrease in $\mathrm{Pb}$ concentrations recorded in the Martot Pond (Figure 5A). This reflects a reduction in the source contribution of $\mathrm{Pb}$ responsible for the elevated concentrations and the strong modification of the isotope ratios during the 1990s and 2000s. As such, there is a correlation between the temporal trend in $\mathrm{Pb}$ concentrations and that of $\mathrm{Pb}$ isotopes, the latter reflecting a major source change for $\mathrm{Pb}$ in the sediment record.

\section{Discussion}

4.1. Evaluation of anthropogenic contribution

The use of EFs to assess the anthropogenic impact of contamination requires the selection of a reference background. In some cases, the reference background used was a GB considered representative of the whole watershed, as for example for the Seine watershed (Horowitz et al., 1999; Thévenot et al., 2007; Le Cloarec et al., 2011), or the reference background was a GB measured at the bottom of sediment cores (Section 3.1.). In other cases, to compensate for the absence of a local GB, some studies have turned to the Upper Continental Crust (UCC) values (Wedepohl, 1995).To assess anthropogenic impacts, EFs were calculated in our study 
from the DAM17-02 core using two reference backgrounds, the local GB defined using the FOR17-02 core and a reference level corresponding to the lowest concentration at the bottom or top of the DAM17-02 core (Table 5). Although the variations in EFs were similar regardless of the reference background, the lowest EFs were those calculated using the reference level (with the exception of As). The strongest EFs were in the 1960-1970s for Cr, $\mathrm{Co}, \mathrm{Ni}, \mathrm{Cu}, \mathrm{Zn}, \mathrm{Ag}, \mathrm{Cd}$.

For $\mathrm{Cr}, \mathrm{Cu}, \mathrm{Zn}$ and $\mathrm{Cd}$, the maximum EFs calculated from the $\mathrm{GB}$ of the Eure watershed, were higher than those for the Oise River, a tributary of the Seine River (Le Cloarec et al., 2011) or the Lot River (with the exception of Zn), a tributary of the Garonne River, known for its historical Cd contamination with industrial origin (Audry et al., 2004). These EFs were still lower than those calculated for the lower reaches of the Seine River, with the exception of $\mathrm{Cu}$ and $\mathrm{Cd}$ (Le Cloarec et al., 2011) but were higher or close to those obtained for other major French rivers such as the Rhône (Ferrand et al., 2012) or Loire rivers (Grosbois et al., 2012; Dhivert et al., 2016). This demonstrates that with regard to these TMMs, anthropogenic pressures within the Eure watershed were higher than those recorded for Oise River, another tributary of the Seine estuary and of the same register as those recorded within major French river watersheds. Conversely, the EFs calculated for As from the reference level were higher but of the same order of magnitude, than those calculated from the GB on the watershed (Table 5). Sediments from the Eure River had a maximum EF at the beginning of the sedimentary record (i.e., during the 1940s), which was lower than the maximum EF calculated in the Oise River or the lower reaches of the Seine River (Le Cloarec et al., 2011). In terms of $\mathrm{Sb}$, the maximum EF (Table 5) was lower than those recorded in the Oise River or the lower reaches of the Seine River (Le Cloarec et al., 2011) whereas for $\mathrm{Pb}$, the maximum EF in the Eure River was higher than most maximum EFs obtained for other watersheds including the Oise (Le Cloarec et al., 2011), Lot (Audry et al., 2004), Rhône (Ferrand et al., 2012) and 
Loire rivers (Grosbois et al., 2012). This highlights the high anthropogenic pressures on the Eure watershed since the 1990s, compared to other French watersheds. Since the 1990s, all of the TMM (except for $\mathrm{Sb}$ and $\mathrm{Pb}$ ) were stable with relatively low concentrations (and $\mathrm{EFs}$ ), which may result from a significant reduction or a halt in additional discharges during the 1960-1970s period. This is assuming that a strong EF corresponds to strong anthropogenic pressure. The lowest levels, considered the baseline within the sediment record, remain higher compared to the GB of the watershed, with the exception of As. This suggests that anthropogenic pressures within the watershed are now low but not null (Table 5). Due to the multiple anthropogenic pressures that a watershed may experience, it can be assumed that soil and sediments quality can only be degraded to pre-industrial revolution levels. As such, EF from the bottom or top of sediment cores, which can be considered permanent anthropogenic baseline, may seem more realistic for the evaluation of anthropogenic pressures in a watershed. This makes it possible to distinguish between periods when anthropogenic pressure is active via industrial, agricultural or even urban discharges, and periods when high levels of TMM (in relation to GB) are solely due to the mechanical erosion of impacted soils or re-suspension of contaminated sediments stored in the river. The remobilisation of contaminated soils has already been observed in small wine-growing watersheds (Sabatier et al., 2014) or those dominated by pastoralism (Bajard et al., 2018).

\subsection{Current and theoretical past contributions}

Over the period 1994-2003, Thévenot et al. (2007) estimated mean annual flux from the Seine watershed to the Seine estuary for $\mathrm{Cr}, \mathrm{Cu}, \mathrm{Zn}, \mathrm{Cd}$ and $\mathrm{Pb}$. Assuming that TMM flux out of the Seine watershed has not changed since this period, this flux out of the Eure watershed for 2017 (Table 3) would be representative of 7, 8, 9, 10, and 16\% of the total inputs (Seine 
River + Eure River) of $\mathrm{Cr}, \mathrm{Cu}, \mathrm{Zn}, \mathrm{Cd}$ and $\mathrm{Pb}$ into the Seine estuary, respectively (Figure 7). It is also interesting to estimate the magnitude of inputs from the Eure watershed in the 1990s, a period when very high $\mathrm{Pb}$ concentrations were recorded. Streamflow in the Eure River has been near constant since 1971 (www.hydro.eaufrance.fr), assuming that 2017 corresponds to a medium hydrological cycle in terms of hydro-sedimentary inputs. As such, theoretical flux estimation for previous years using the SPM flux for the year 2017 and annual TMM concentrations within sediment cores could prove insightful. The average $\mathrm{Pb}$ concentration over 1992-1996 was $846 \mathrm{mg} \mathrm{kg}^{-1}$ (Figure 6; Table 3), which equates to an average flux of $95 \mathrm{t}$ $\mathrm{y}^{-1}$, making the Eure watershed the main contributor of $\mathrm{Pb}$ to the Seine estuary (52\%) (Figure 7). This confirms the river's classification as very high contamination by Meybeck et al. (2004), and that the watershed has recently experienced major $\mathrm{Pb}$ contamination with little national equivalency.

\subsection{Sources of contamination}

Similar temporal trends for $\mathrm{Cr}, \mathrm{Co}, \mathrm{Ni}, \mathrm{Cu}, \mathrm{Zn}, \mathrm{Ag}, \mathrm{Cd}$ (Figures $5 \mathrm{~A}$ and 6) suggest that a single anthropogenic source was responsible for the high levels over the 1960s-1970s. The presence of $\mathrm{Cd}, \mathrm{Ni}, \mathrm{Zn}$ could be related to the activities and discharges of a saline batteries factory. Within the Eure watershed there was a saline batteries factory (opened in the late 1930s), supplying most of the national market during the 1960s, resulting in very high localised production. The factory was the subject of an increased administrative survey by a national agency in the early 1970s (Agence Financière de Bassin “Seine-Normandie," 1971). This survey, coupled with the development of alkaline batteries (manufactured abroad), may have caused a drop in production, resulting in a reduction in concentrations after the 1970s, until the closure of the industrial site in 1994 (Gardes et al., 2020a). 
The main source responsible for As release has not been defined but may be attributed to different anthropogenic activities. This includes discharge from agricultural activities (e.g., wood preservative), industrial activities (glass and electronics industry, metal treatment, ammunition manufacturing, production of dyes and colorants or metal smelters smelting) or coal combustion (Reimann et al., 2009). But it must be noted that arsenical herbicides have been forbidden in France since 1973; it is probable that it was one of the main sources in the Eure watershed as the current concentrations, near the GB value, were reached after the 1970s.

Sources responsible for $\mathrm{Pb}$ contamination can be discriminated from $\mathrm{Pb}$ isotopes, particularly in tri-isotopic diagrams in which these potential sources act as end-members (e.g., Cloquet et al., 2015). In the diagram ${ }^{208} \mathrm{~Pb} /{ }^{206} \mathrm{~Pb}$ versus ${ }^{206} \mathrm{~Pb} /{ }^{207} \mathrm{~Pb}$, the measurement within the Seine Unit $\mathrm{U} 2\left({ }^{208} \mathrm{~Pb} /{ }^{206} \mathrm{~Pb}=2.070\right.$ and $\left.{ }^{206} \mathrm{~Pb} /{ }^{207} \mathrm{~Pb}=1.193\right)$ was close to the points with a natural (or pre-industrial) signature $\left({ }^{208} \mathrm{~Pb} /{ }^{206} \mathrm{~Pb}=2.053\right.$ and ${ }^{206} \mathrm{~Pb} /{ }^{207} \mathrm{~Pb}=1.2007$, ElbazPoulichet et al., 1986; ${ }^{208} \mathrm{~Pb} /{ }^{206} \mathrm{~Pb}=2.066$ and ${ }^{206} \mathrm{~Pb} /{ }^{207} \mathrm{~Pb}=1.197$, Monna et al., 1997; ${ }^{208} \mathrm{~Pb} /{ }^{206} \mathrm{~Pb}=2.079$ and ${ }^{206} \mathrm{~Pb} /{ }^{207} \mathrm{~Pb}=1.200$, Ferrand et al., 1999) (Figure 8A). Moreover, such a high ${ }^{206} \mathrm{~Pb} /{ }^{207} \mathrm{~Pb}$ ratio has never been previously recorded in the Seine watershed (Ayrault et al., 2012) with the exception of the upstream Yonne River where ${ }^{206} \mathrm{~Pb} /{ }^{207} \mathrm{~Pb}$ was approximately 1.19 prior to the 1960 s and after the 2000s. This reflects an absence of anthropogenic $\mathrm{Pb}$ contamination (Ayrault et al., 2010). In terms of the Eure Unit U1, the signature measured in $1965\left({ }^{208} \mathrm{~Pb} /{ }^{206} \mathrm{~Pb}=2.097\right.$ et $\left.{ }^{206} \mathrm{~Pb} /{ }^{207} \mathrm{~Pb}=1.170\right)$ showed a mix between pre-industrial and industrial poles. It is possible to assess the relative contribution of a source using the binary model, described for example by Komárek et al. (2008). Based on the ${ }^{206} \mathrm{~Pb} /{ }^{207} \mathrm{~Pb}$ ratio proposed by Monna et al. (1997) as the average signature of French industrial $\mathrm{Pb}\left({ }^{206} \mathrm{~Pb} /{ }^{207} \mathrm{~Pb}=1.155\right)$, the contribution of the unidentified industrial source, was in the range $60-67 \%$. This is dependent on the value used for the pre-industrial source, 
between the Seine Unit from this study, and the values proposed by Elbaz-Poulichet et al. (1986), Monna et al. (1997) and Ferrand et al. (1999). This shows that the contribution of anthropogenic $\mathrm{Pb}$ was already significant during the 1960s in the Eure watershed, whereas $\mathrm{Pb}$ concentrations recorded in sediment cores at the same time were not high and did not exhibit an increasing trend (Figure 5A). However, the estimation of this contribution does not consider a possible existing contribution from other sources such as coal use (e.g., coal power plant, coal combustion), which is also a source of $\mathrm{Pb}$. Notably, the isotope signature recorded in 1965 was close to the isotope signatures of $\mathrm{Pb}$ from coal use (Cloquet et al., 2006; ElbazPoulichet et al., 2011). Although it is unlikely that there existed only a single source emitting $\mathrm{Pb}$ during the 1960s. This 1960s signature was close to the European Standard Lead Pollution (ESLP) line defined by Haack et al. (2002, 2003) from atmospheric Pb deposition across Europe, confirming the presence of anthropogenic $\mathrm{Pb}$ in this sample. More recent contamination signatures (1995, 1997, 2002 and 2012) were located between the industrial and leaded petrol poles (defined from data from Monna et al. (1997), Véron et al. (1999) and Cloquet et al. (2015)). These were aligned with the industrial $\mathrm{Pb}$ line also defined by Haack et al. (2002, 2003) from industrial equipment, exhaust pipes and several major ore deposits. As such, it is possible to envisage a mixture between these two poles to understand the signatures obtained recently in the Eure watershed. Figure 8B shows that these signatures, in particular that of 1995, were close to a $\mathrm{Pb}$ smelting signature defined in northern France from aerosols $\left(\mathrm{n}=2 ;{ }^{208} \mathrm{~Pb} /{ }^{206} \mathrm{~Pb}=2.1269 \pm 0.0008\right.$ et ${ }^{206} \mathrm{~Pb} /{ }^{207} \mathrm{~Pb}=1.1330 \pm 0.0009$ (Véron et al., 1999)), or dust from a $\mathrm{Pb}-\mathrm{Zn}$ smelting plant $\left(\mathrm{n}=2 ;{ }^{208} \mathrm{~Pb} /{ }^{206} \mathrm{~Pb}=2.124 \pm 0.002\right.$ et ${ }^{206} \mathrm{~Pb} /{ }^{207} \mathrm{~Pb}=$ $1.1289 \pm 0.0023$ (Cloquet et al., 2006)) (not shown in Figure 8B). However, these authors do not consider contributions from leaded gasoline. Therefore, the signature recorded here for these four points was the result of an anthropogenic $\mathrm{Pb}$ input, the partial source of which could be the same as that recorded by the signature measured in 1965 . The difference in 
signature between 1965 and more recent signatures may also be attributable to an increase in a major anthropogenic source not yet identified but unrelated to coal (indicated by increases in $\mathrm{Pb}$ concentrations as seen in the sediment cores). There is an anthropogenic source of $\mathrm{Pb}$ in the Eure watershed related to industrial activities that commenced in the 1960s and increased from the 1990s. Chiffoleau et al. (2012) used a sediment core sampled in the Seine estuary to demonstrate that there was a single anthropogenic source which accounts for the variations in the ${ }^{206} \mathrm{~Pb} /{ }^{207} \mathrm{~Pb}$ ratio in the estuary since 1975 . Between 1975 and 1985 the variations in this ratio are explained by a mixture between intra-estuarine phosphogypsum discharges and an unknown anthropogenic source Post-1985 the variations may be attributed to a mixture between a natural source and this same unknown anthropogenic source. The isotopic signature of this source $\left({ }^{208} \mathrm{~Pb} /{ }^{206} \mathrm{~Pb}=2.132\right.$ et $\left.{ }^{206} \mathrm{~Pb} /{ }^{207} \mathrm{~Pb}=1.13\right)$ was isolated by Chiffoleau et al. (2012) and Figure 8B shows that it is close to the anthropogenic signature recorded by the Eure River sediments, indicating that it is likely the source comes from the Eure River. Based on the SPM sampled in the Eure River in March and September 2009 (and of dissolved $\mathrm{Pb}$ $\left(\mathrm{Pb}_{\mathrm{d}}\right)$ measurements), Chiffoleau et al. (2012) estimated a low ${ }^{206} \mathrm{~Pb} /{ }^{207} \mathrm{~Pb}$ ratio, in the range $1.12-1.14$, consistent with ratios from our study (Figure 8B). From a sampling campaign conducted in September 2011, Chiffoleau et al. (2012) found an increase in $\mathrm{Pb}_{\mathrm{d}}$ and a ${ }^{206} \mathrm{~Pb} /{ }^{207} \mathrm{~Pb}$ ratio of about 1.13 downstream of the city of Dreux (and a ${ }^{206} \mathrm{~Pb} /{ }^{207} \mathrm{~Pb}$ ratio greater than 1.14 upstream). Assuming the mixture of natural and anthropogenic sources, the authors estimated that the additional anthropogenic source had a ${ }^{206} \mathrm{~Pb} /{ }^{207} \mathrm{~Pb}$ signature of approximately 1.12. A cathode-ray tube (CRT) factory began operation in Dreux in 1956 and a second factory, specialising in the assembly of CRT TVs and the manufacture of electrical circuits, opened in 1974 at the same industrial site. Chiffoleau et al. (2012) hypothesised that the CRT factory represented this unknown $\mathrm{Pb}$ source. CRT may contain up to $3 \mathrm{~kg}$ of $\mathrm{Pb}$ (Tsydenova and Bengtsson, 2011). This factory, as well as the CRT TVs assembly factory, 
was purchased in the early 1990s to boost the economy (and thus increase CRT production) prior to closing in 2006 and 2010 for the CRT factory and CRT TVs assembly factory, respectively. In 2001, $\mathrm{Pb}$ discharge to water from the industrial site was ranked among the highest in Europe by the European Environment Agency (E-PRTR, 2006). Increases in $\mathrm{Pb}_{\mathrm{p}}$ within sediment cores since the 1990s, as well as isotope signatures measured in 1995, 1997 and 2002, reflect the economic recovery initiated by this industry. However, the high concentrations measured from the end of the 2000s in the sediment cores, and the isotopic signature estimated in 2012, demonstrate that anthropogenic $\mathrm{Pb}$ inputs are still present in the Eure watershed despite the cessation of industrial activities. These inputs are sufficiently high to modify the ${ }^{206} \mathrm{~Pb} /{ }^{207} \mathrm{~Pb}$ ratio in the SPM of the Seine estuary as shown by Chiffoleau et al. (2012).

\section{Conclusions}

This study of sediment cores has revealed that the lower reaches of the Eure watershed have been subject to significant anthropogenic pressures since the 1940s, at comparable or higher levels, than those experienced by other French watersheds during the twentieth century. The temporal trends of TMM concentrations have shown strong anthropogenic impacts, mainly of industrial origin during the 1960s and 1970s. A general trend towards a decrease in impacts was emerging at the end of the twentieth century, as in the majority of French river watersheds. However, an additional source, potentially of industrial origin, was responsible for high $\mathrm{Pb}$ discharges that heavily contaminated sediments of the Eure River. It had a signature found in sediments of the Seine estuary, that had already been heavily impacted by inputs from the fluvial part of Seine River, one of the most anthropized catchments in Europe. The similarity between the levels of TMM in the most recent sedimentary deposits and on the 
SPM showed that the sedimentary records were representative of SPM transfers, and that the footprint of industrial contamination was still present despite the cessation of the activities responsible for the discharges. This footprint reflects the existence of permanent anthropogenic baseline within the river, resulting from the erosion of contaminated soils and sediments stored in the river and remobilised during floods and/or landscaping projects. As a result, the current flux in TMM to the Seine estuary remain significant despite the cessation or drastic reduction of discharges from anthropogenic activities. Based on the estimation of past theoretical flows, it has been shown in the case of $\mathrm{Pb}$ that the Eure watershed could exceed contributions from the Seine watershed, making the former the main contributor of $\mathrm{Pb}$ to the Seine estuary during the 1990s.

\section{Reference data}

The dataset is available at https://doi.org/10.1594/PANGAEA.912843 (Gardes et al., 2020b) and at https://doi.org/10.1594/PANGAEA.911102 (Gardes et al., 2020c).

\section{Acknowledgements}

This work is part of the OSS 276 project, financially supported by the Seine-Normandie Water Agency (France). This work is support by the CNRS toward EC2CO grant (AvantSeine project). Gardes Th. grant was funded by the Region Normandie, which supports the scientific consortium SCALE UMR CNRS 3730. CNRS also supports the French national cyber-Repository (https://www.cybercarotheque.fr/) which is a portal for metadata associated with marine, lake/river sediment cores stored in French laboratories. This project was initiated by CLIMCOR project (http://climcor-equipex.dt.insu.cnrs.fr/).

Our paper is a contribution to ROZA-LTER-fr project : Retro-Observatory of sedimentary Archive from French LTER (http://ccwbvps18.in2p3.fr/maps/visualiseur-coyoxhup\#project) which is a portal for data associated with marine, lake sediment cores stored in LTER French laboratories.

Authors sincerely thank the "Parc Naturel Régional du Perche" for allowing the access at the ponds and Aurélie Tran Van Loc for her participation at the coring session. 
Authors also thank Romain Levaillant and Michel Simon (M2C laboratory) for their participation in the field sampling (coring sessions, TIMS deployment).

\section{References}

Ackermann, F., 1980. A procedure for correcting the grain size effect in heavy metal analyses of estuarine and coastal sediments. Environ. Technol. Lett. 1, 518-527. https://doi.org/10.1080/09593338009384008

Agence Financière de Bassin "Seine-Normandie," 1971. Délibération n71-16 du 21 Octobre 1971 désignant les entreprises industrielles soumises à la mesure pour le calcul de leur redevance pollution.

Appleby, P.G., Richardson, N., Nolan, P.J., 1991. 241Am dating of lake sediments. Hydrobiologia 214, 35-42. https://doi.org/10.1007/BF00050929

Audry, S., Blanc, G., Schäfer, J., Chaillou, G., Robert, S., 2006. Early diagenesis of trace metals $(\mathrm{Cd}, \mathrm{Cu}, \mathrm{Co}, \mathrm{Ni}, \mathrm{U}, \mathrm{Mo}$, and $\mathrm{V})$ in the freshwater reaches of a macrotidal estuary. Geochim. Cosmochim. Acta 70, 2264-2282. https://doi.org/10.1016/j.gca.2006.02.001

Audry, S., Schäfer, J., Blanc, G., Jouanneau, J.-M., 2004. Fifty-year sedimentary record of heavy metal pollution $(\mathrm{Cd}, \mathrm{Zn}, \mathrm{Cu}, \mathrm{Pb})$ in the Lot River reservoirs (France). Environ. Pollut. 132, 413-426. https://doi.org/10.1016/j.envpol.2004.05.025

Ayrault, S., Lorgeoux, C., Moilleron, R., Lherm, D., Tassin, B., Bonté, P., Roy-Barman, M., Le, M.-F., Lefèvre, I., Priadi, C., Evrard, O., Bordier, L., Mouchel, J.-M., Eurin, J., Tamtam, F., Dinh, T., Boust, D., Vrel, A., 2010. Archives sédimentaires, empreintes des micropolluants sur le bassin de la Seine sur 80 ans. PIREN-Seine Rapp. Act. 2010 34.

Ayrault, S., Roy-Barman, M., Le Cloarec, M.-F., Priadi, C.R., Bonté, P., Göpel, C., 2012. Lead contamination of the Seine River, France: Geochemical implications of a historical perspective. Chemosphere 87, 902-910. https://doi.org/10.1016/j.chemosphere.2012.01.043

Bábek, O., Grygar, T.M., Faměra, M., Hron, K., Nováková, T., Sedláček, J., 2015. Geochemical background in polluted river sediments: How to separate the effects of sediment provenance and grain size with statistical rigour? CATENA 135, 240-253. https://doi.org/10.1016/j.catena.2015.07.003

Bajard, M., Etienne, D., Quinsac, S., Dambrine, E., Sabatier, P., Frossard, V., Gaillard, J., Develle, A.-L., Poulenard, J., Arnaud, F., Dorioz, J.-M., 2018. Legacy of early anthropogenic effects on recent lake eutrophication (Lake Bénit, northern French Alps). Anthropocene 24, 72-87. https://doi.org/10.1016/j.ancene.2018.11.005

Bruel, R., Sabatier, P., 2020. serac: a R package for ShortlivEd RAdionuclide Chronology of recent sediment cores. EarthArXiv 1-38. https://doi.org/10.31223/osf.io/f4yma

Brügmann, L., 1995. Metals in sediments and suspended matter of the river Elbe. Sci. Total Environ. 159, 53-65. https://doi.org/10.1016/0048-9697(94)04252-I

Callender, E., 2000. Geochemical effects of rapid sedimentation in aquatic systems: minimal diagenesis and the preservation of historical metal signatures. J. Paleolimnol. 23, 243260. https://doi.org/10.1023/A:1008114630756

Chiaradia, M., Gallay, A., Todt, W., 2003. Different contamination styles of prehistoric human teeth at a Swiss necropolis (Sion, Valais) inferred from lead and strontium isotopes. Appl. Geochem. 18, 353-370. https://doi.org/10.1016/S08832927(02)00072-0 
Chiffoleau, J.-F., Sonke, J.E., Auger, D., Bretaudeau, J., Joguet, T., Larrieu, M., Laffont, L., Prunier, J., Rozuel, E., Zouiten, C., 2012. Etude de la signature isotopique des métaux dans l'estuaire de la Seine. Une information essentielle pour le traçage et la discrimination des sources et processus.

Cloquet, C., Carignan, J., Libourel, G., 2006a. Atmospheric pollutant dispersion around an urban area using trace metal concentrations and $\mathrm{Pb}$ isotopic compositions in epiphytic lichens. Atmos. Environ. 40, 574-587. https://doi.org/10.1016/j.atmosenv.2005.09.073

Cloquet, C., Carignan, J., Libourel, G., Sterckeman, T., Perdrix, E., 2006b. Tracing Source Pollution in Soils Using Cadmium and Lead Isotopes. Environ. Sci. Technol. 40, 2525-2530. https://doi.org/10.1021/es052232+

Cloquet, C., Estrade, N., Carignan, J., 2015. Ten years of elemental atmospheric metal fallout and $\mathrm{Pb}$ isotopic composition monitoring using lichens in northeastern France.

Comptes Rendus Geosci., Geochemical and isotopic record of anthropogenic activities (Part 1) 347, 257-266. https://doi.org/10.1016/j.crte.2015.04.003

Copard, Y., Di- Giovanni, C., Martaud, T., Albéric, P., Olivier, J.-E., 2006. Using Rock-Eval 6 pyrolysis for tracking fossil organic carbon in modern environments: implications for the roles of erosion and weathering. Earth Surf. Process. Landf. 31, 135-153. https://doi.org/10.1002/esp.1319

Coynel, A., Gorse, L., Curti, C., Schafer, J., Grosbois, C., Morelli, G., Ducassou, E., Blanc, G., Maillet, G.M., Mojtahid, M., 2016. Spatial distribution of trace elements in the surface sediments of a major European estuary (Loire Estuary, France): Source identification and evaluation of anthropogenic contribution. J. Sea Res., Recent and past sedimentary, biogeochemical and benthic ecosystem evolution of the Loire Estuary (Western France) 118, 77-91. https://doi.org/10.1016/j.seares.2016.08.005

Coynel, A., Schäfer, J., Blanc, G., Bossy, C., 2007. Scenario of particulate trace metal and metalloid transport during a major flood event inferred from transient geochemical signals. Appl. Geochem. 22, 821-836.

https://doi.org/10.1016/j.apgeochem.2006.10.004

Daskalakis, K.D., O’Connor, T.P., 1995. Normalization and Elemental Sediment Contamination in the Coastal United States. Environ. Sci. Technol. 29, 470-477. https://doi.org/10.1021/es00002a024

Dhivert, E., Grosbois, C., Courtin-Nomade, A., Bourrain, X., Desmet, M., 2016. Dynamics of metallic contaminants at a basin scale - Spatial and temporal reconstruction from four sediment cores (Loire fluvial system, France). Sci. Total Environ. 541, 15041515. https://doi.org/10.1016/j.scitotenv.2015.09.146

Duan, D., Ran, Y., Cheng, H., Chen, J., Wan, G., 2014. Contamination trends of trace metals and coupling with algal productivity in sediment cores in Pearl River Delta, South China. Chemosphere 103, 35-43. https://doi.org/10.1016/j.chemosphere.2013.11.011

Elbaz-Poulichet, F., Dezileau, L., Freydier, R., Cossa, D., Sabatier, P., 2011. A 3500-Year Record of $\mathrm{Hg}$ and $\mathrm{Pb}$ Contamination in a Mediterranean Sedimentary Archive (The Pierre Blanche Lagoon, France). Environ. Sci. Technol. 45, 8642-8647. https://doi.org/10.1021/es2004599

Elbaz-Poulichet, F., Guédron, S., Anne-Lise, D., Freydier, R., Perrot, V., Rossi, M., Piot, C., Delpoux, S., Sabatier, P., 2020. A 10,000-year record of trace metal and metalloid $(\mathrm{Cu}, \mathrm{Hg}, \mathrm{Sb}, \mathrm{Pb})$ deposition in a western Alpine lake (Lake Robert, France): Deciphering local and regional mining contamination. Quat. Sci. Rev. 228, 106076. https://doi.org/10.1016/j.quascirev.2019.106076

Elbaz-Poulichet, F., Holliger, P., Martin, J.M., Petit, D., 1986. Stable lead isotopes ratios in major french rivers and estuaries. Sci. Total Environ. 54, 61-76. https://doi.org/10.1016/0048-9697(86)90256-1 
E-PRTR [WWW Document], 2006. . Eur. Environ. Agency. URL

https://www.eea.europa.eu/data-and-maps/data/member-states-reporting-art-7-underthe-european-pollutant-release-and-transfer-register-e-prtr-regulation-18 (accessed 6.4.19).

Ferrand, E., Eyrolle, F., Radakovitch, O., Provansal, M., Dufour, S., Vella, C., Raccasi, G., Gurriaran, R., 2012. Historical levels of heavy metals and artificial radionuclides reconstructed from overbank sediment records in lower Rhône River (South-East France). Geochim. Cosmochim. Acta, Environmental Records of Anthropogenic Impacts 82, 163-182. https://doi.org/10.1016/j.gca.2011.11.023

Ferrand, J.-L., Hamelin, B., Monaco, A., 1999. Isotopic tracing of anthropogenic $\mathrm{Pb}$ inventories and sedimentary fluxes in the Gulf of Lions (NW Mediterranean sea). Cont. Shelf Res. 19, 23-47. https://doi.org/10.1016/S0278-4343(98)00070-3

Foster, I.D.L., Charlesworth, S.M., 1996. Heavy metals in the hydrological cycle: Trends and explanation. Hydrol. Process. 10, 227-261. https://doi.org/10.1002/(SICI)10991085(199602)10:2<227::AID-HYP357>3.0.CO;2-X

Gale, N.H., 1996. A new method for extracting and purifying lead from difficult matrices for isotopic analysis. Anal. Chim. Acta 332, 15-21. https://doi.org/10.1016/00032670(96)00207-3

Gardes, T., Debret, M., Copard, Y., Patault, E., Winiarski, T., Develle, A.-L., Sabatier, P., Dendievel, A.-M., Mourier, B., Marcotte, S., Leroy, B., Portet-Koltalo, F., 2020a. Reconstruction of anthropogenic activities in legacy sediments from the Eure River, a major tributary of the Seine Estuary (France). CATENA 190, 104513. https://doi.org/10.1016/j.catena.2020.104513

Gardes, T., Debret, M., Copard, Y., Coynel, A., Deloffre, J., Fournier, M., Revillon, S., Nizou, J., Develle, A.-L., Sabatier, P., Marcotte, S., Patault, E., Faivre, Q., PortetKoltalo, F., 2020b. Trace metals and metalloid elements in sediment cores (1940s2017) and suspended particulate matter (2017-2018) from the Eure River, France. PANGAEA. https://doi.org/10.1594/PANGAEA.912843

Gardes, T., Debret, M., Copard, Y., Patault, E., Winiarski, T., Develle, A.-L., Sabatier, P., Dendievel, A.-M., Mourier, B., Marcotte, S., Leroy, B., Portet-Koltalo, F., 2020c. Reconstruction of anthropogenic activites in sediments cores from the Eure River. PANGAEA. https://doi.org/10.1594/PANGAEA.911102

Gascón Díez, E., Corella, J.P., Adatte, T., Thevenon, F., Loizeau, J.-L., 2017. High-resolution reconstruction of the 20th century history of trace metals, major elements, and organic matter in sediments in a contaminated area of Lake Geneva, Switzerland. Appl. Geochem. 78, 1-11. https://doi.org/10.1016/j.apgeochem.2016.12.007

Goldberg, E.L., 1963. Geochronology with 210Pb. Radioact. Dating Int. At. Energy Agency 121-131.

Grosbois, C., Meybeck, M., Lestel, L., Lefèvre, I., Moatar, F., 2012. Severe and contrasted polymetallic contamination patterns (1900-2009) in the Loire River sediments (France). Sci. Total Environ. 435-436, 290-305. https://doi.org/10.1016/j.scitotenv.2012.06.056

Grousset, F.E., Jouanneau, J.M., Castaing, P., Lavaux, G., Latouche, C., 1999. A 70 year Record of Contamination from Industrial Activity Along the Garonne River and its Tributaries (SW France). Estuar. Coast. Shelf Sci. 48, 401-414. https://doi.org/10.1006/ecss.1998.0435

Haack, U.K., Gutsche, F.H., Plessow, K., Heinrichs, H., 2002. On the Isotopic Composition of $\mathrm{Pb}$ in Cloud Waters in Central Germany. A Source Discrimination Study. Water. Air. Soil Pollut. 139, 261-288. https://doi.org/10.1023/A:1015864103834 
Haack, U.K., Heinrichs, H., Gutsche, F.H., Plessow, K., 2003. The Isotopic Composition of Anthropogenic $\mathrm{Pb}$ in Soil Profiles of Northern Germany: Evidence for Pollutant $\mathrm{Pb}$ from a Continent-wide Mixing System. Water. Air. Soil Pollut. 150, 113-134. https://doi.org/10.1023/A:1026142501593

He, Q., Walling, D.E., 1996. Interpreting particle size effects in the adsorption of 137Cs and unsupported $210 \mathrm{~Pb}$ by mineral soils and sediments. J. Environ. Radioact. 30, 117-137. https://doi.org/10.1016/0265-931X(96)89275-7

Hennekam, R., Sweere, T., Tjallingii, R., de Lange, G.J., Reichart, G.-J., 2019. Trace metal analysis of sediment cores using a novel X-ray fluorescence core scanning method. Quat. Int., Advances in Data Quantification and Application of high resolution XRF Core Scanners 514, 55-67. https://doi.org/10.1016/j.quaint.2018.10.018

Horowitz, A.J., Elrick, K.A., 1987. The relation of stream sediment surface area, grain size and composition to trace element chemistry. Appl. Geochem. 2, 437-451. https://doi.org/10.1016/0883-2927(87)90027-8

Horowitz, A.J., Meybeck, M., Idlafkih, Z., Biger, E., 1999. Variations in trace element geochemistry in the Seine River Basin based on floodplain deposits and bed sediments. Hydrol. Process. 13, 1329-1340. https://doi.org/10.1002/(SICI)10991085(19990630)13:9<1329::AID-HYP811>3.0.CO;2-H

Komárek, M., Ettler, V., Chrastný, V., Mihaljevič, M., 2008. Lead isotopes in environmental sciences: A review. Environ. Int. 34, 562-577. https://doi.org/10.1016/j.envint.2007.10.005

Krishnaswamy, S., Lal, D., Martin, J.M., Meybeck, M., 1971. Geochronology of lake sediments. Earth Planet. Sci. Lett. 11, 407-414. https://doi.org/10.1016/0012821X(71)90202-0

Laignel, B., Quesnel, F., Lecoustumer, M.-N., Meyer, R., 1998. Variabilité du cortège argileux des formations résiduelles à silex de l'Ouest du bassin de Paris. Comptes Rendus Académie Sci. - Ser. IIA - Earth Planet. Sci. 326, 467-472. https://doi.org/10.1016/S1251-8050(98)80072-4

Lanceleur, L., Schäfer, J., Bossy, C., Coynel, A., Larrose, A., Masson, M., Blanc, G., 2011a. Silver fluxes to the Gironde Estuary - Eleven years (1999-2009) of monitoring at the watershed scale. Appl. Geochem. 26, 797-808. https://doi.org/10.1016/j.apgeochem.2011.02.001

Lanceleur, L., Schäfer, J., Chiffoleau, J.-F., Blanc, G., Auger, D., Renault, S., Baudrimont, M., Audry, S., 2011b. Long-term records of cadmium and silver contamination in sediments and oysters from the Gironde fluvial-estuarine continuum - Evidence of changing silver sources. Chemosphere 85, 1299-1305. https://doi.org/10.1016/j.chemosphere.2011.07.036

Larrose, A., Coynel, A., Schäfer, J., Blanc, G., Massé, L., Maneux, E., 2010. Assessing the current state of the Gironde Estuary by mapping priority contaminant distribution and risk potential in surface sediment. Appl. Geochem. 25, 1912-1923. https://doi.org/10.1016/j.apgeochem.2010.10.007

Le Cloarec, M.-F., Bonte, P.H., Lestel, L., Lefèvre, I., Ayrault, S., 2011. Sedimentary record of metal contamination in the Seine River during the last century. Phys. Chem. Earth Parts ABC, Man and River Systems: From pressures to physical, chemical and ecological status 36, 515-529. https://doi.org/10.1016/j.pce.2009.02.003

Lepland, Aivo, Andersen, T.J., Lepland, Aave, Arp, H.P.H., Alve, E., Breedveld, G.D., Rindby, A., 2010. Sedimentation and chronology of heavy metal pollution in Oslo harbor, Norway. Mar. Pollut. Bull. 60, 1512-1522. https://doi.org/10.1016/j.marpolbul.2010.04.017 
Masson, M., Blanc, G., Schäfer, J., Parlanti, E., Le Coustumer, P., 2011. Copper addition by organic matter degradation in the freshwater reaches of a turbid estuary. Sci. Total Environ. 409, 1539-1549. https://doi.org/10.1016/j.scitotenv.2011.01.022

Meybeck, M., Horowitz, A.J., Grosbois, C., 2004. The geochemistry of Seine River Basin particulate matter: distribution of an integrated metal pollution index. Sci. Total Environ. 328, 219-236. https://doi.org/10.1016/j.scitotenv.2004.01.024

Monna, F., Lancelot, J., Croudace, I.W., Cundy, A.B., Lewis, J.T., 1997. Pb Isotopic Composition of Airborne Particulate Material from France and the Southern United Kingdom: Implications for $\mathrm{Pb}$ Pollution Sources in Urban Areas. Environ. Sci. Technol. 31, 2277-2286. https://doi.org/10.1021/es960870+

Petit, J.C.J., Schäfer, J., Coynel, A., Blanc, G., Deycard, V.N., Derriennic, H., Lanceleur, L., Dutruch, L., Bossy, C., Mattielli, N., 2013. Anthropogenic sources and biogeochemical reactivity of particulate and dissolved $\mathrm{Cu}$ isotopes in the turbidity gradient of the Garonne River (France). Chem. Geol. 359, 125-135. https://doi.org/10.1016/j.chemgeo.2013.09.019

Phillips, J.M., Russell, M.A., Walling, D.E., 2000. Time-integrated sampling of fluvial suspended sediment: a simple methodology for small catchments. Hydrol. Process. 14, 2589-2602. https://doi.org/10.1002/1099-1085(20001015)14:14<2589::AIDHYP94>3.0.CO;2-D

Quesnel, F., 1997. Digital mapping in regolith geology. Cartographie numérique en géologie de surface. Application aux altérites à silex de l'Ouest du bassin de Paris (Theses). Université de Rouen.

Reimann, C., Matschullat, J., Birke, M., Salminen, R., 2009. Arsenic distribution in the environment: The effects of scale. Appl. Geochem. 24, 1147-1167. https://doi.org/10.1016/j.apgeochem.2009.03.013

Reimer, P.J., Bard, E., Bayliss, A., Beck, J.W., Blackwell, P.G., Ramsey, C.B., Buck, C.E., Cheng, H., Edwards, R.L., Friedrich, M., Grootes, P.M., Guilderson, T.P., Haflidason, H., Hajdas, I., Hatté, C., Heaton, T.J., Hoffmann, D.L., Hogg, A.G., Hughen, K.A., Kaiser, K.F., Kromer, B., Manning, S.W., Niu, M., Reimer, R.W., Richards, D.A., Scott, E.M., Southon, J.R., Staff, R.A., Turney, C.S.M., Plicht, J. van der, 2013. IntCal13 and Marine13 Radiocarbon Age Calibration Curves 0-50,000 Years cal BP. Radiocarbon 55, 1869-1887. https://doi.org/10.2458/azu_js_rc.55.16947

Richter, T.O., Gaast, S. van der, Koster, B., Vaars, A., Gieles, R., Stigter, H.C. de, Haas, H.D., Weering, T.C.E. van, 2006. The Avaatech XRF Core Scanner: technical description and applications to NE Atlantic sediments. Geol. Soc. Lond. Spec. Publ. 267, 39-50. https://doi.org/10.1144/GSL.SP.2006.267.01.03

Robbins, J.A., Edgington, D.N., 1975. Determination of recent sedimentation rates in Lake Michigan using Pb-210 and Cs-137. Geochim. Cosmochim. Acta 39, 285-304. https://doi.org/10.1016/0016-7037(75)90198-2

Russell, M.A., Walling, D.E., Hodgkinson, R.A., 2000. Appraisal of a simple sampling device for collecting time-integrated fluvial suspended sediment samples. The role of erosion and sediment transport in nutrient and contaminant transfer (Proceedings Waterloo Symposium, 2000). IAHS Publ. 263, 119-127.

Sabatier, P., Poulenard, J., Fanget, B., Reyss, J.-L., Develle, A.-L., Wilhelm, B., Ployon, E., Pignol, C., Naffrechoux, E., Dorioz, J.-M., Montuelle, B., Arnaud, F., 2014. Longterm relationships among pesticide applications, mobility, and soil erosion in a vineyard watershed. Proc. Natl. Acad. Sci. U. S. A. 111, 15647-15652. https://doi.org/10.1073/pnas.1411512111

Salomons, W., Forstner, U., 1984. Metals in the hydrocycle. Met. Hydrocycle. 
Thévenot, D., Moilleron, R., Lestel, L., Gromaire, M.C., Rocher, V., Cambier, P., Bonté, P., Colin, J.-. L., de Ponteves, C., Meybeck, M., 2007. Critical budget of metal sources and pathways in the Seine River basin (1994-2003) for $\mathrm{Cd}, \mathrm{Cr}, \mathrm{Cu}, \mathrm{Hg}, \mathrm{Ni}, \mathrm{Pb}$ and $\mathrm{Zn}$. Sci. Total Environ. 375.

Tseng, C.M., Amouroux, D., Abril, G., Tessier, E., Etcheber, H., Donard, O.F.X., 2001. Speciation of Mercury in a Fluid Mud Profile of a Highly Turbid Macrotidal Estuary (Gironde, France). Environ. Sci. Technol. 35, 2627-2633. https://doi.org/10.1021/es001750b

Tsydenova, O., Bengtsson, M., 2011. Chemical hazards associated with treatment of waste electrical and electronic equipment. Waste Manag. 31, 45-58. https://doi.org/10.1016/j.wasman.2010.08.014

Van Calsteren, P., Thomas, L., 2006. Uranium-series dating applications in natural environmental science. Earth-Sci. Rev., ISOtopes in PALaeoenvironmental reconstruction (ISOPAL) 75, 155-175. https://doi.org/10.1016/j.earscirev.2005.09.001

Véron, A., Flament, P., Bertho, M.L., Alleman, L., Flegal, R., Hamelin, B., 1999. Isotopic evidence of pollutant lead sources in Northwestern France. Atmos. Environ. 33, 33773388. https://doi.org/10.1016/S1352-2310(98)00376-8

Vrel, A., 2012. Reconstitution de l'historique des apports en radionucléides et contaminants métalliques à l'estuaire fluvial de la Seine par l'analyse de leur enregistrement sédimentaire.

Wedepohl, K.H., 1995. The composition of the continental crust. Geochim. Cosmochim. Acta 59, 1217-1232. https://doi.org/10.1016/0016-7037(95)00038-2

White, W.M., Albarède, F., Télouk, P., 2000. High-precision analysis of Pb isotope ratios by multi-collector ICP-MS. Chem. Geol. 167, 257-270. https://doi.org/10.1016/S00092541(99)00182-5 
CRediT author statement:

Thomas Gardes: Conceptualization, Validation, Formal analysis, Investigation, Resources, Writing - Original Draft, Writing - Review \& Editing, Visualization

Maxime Debret: Conceptualization, Resources, Writing - Review \& Editing, Supervision, Project administration, Funding acquisition

Yoann Copard: Conceptualization, Writing - Review \& Editing, Supervision

Alexandra Coynel: Investigation, Resources, Writing - Review \& Editing

Julien Deloffre: Formal analysis, Writing - Review \& Editing

Matthieu Fournier: Formal analysis, Writing - Review \& Editing

Sidonie Revillon: Investigation, Resources, Writing - Review \& Editing

Jean Nizou: Investigation, Resources, Writing - Review \& Editing

Anne-Lise Develle: Investigation, Resources, Writing - Review \& Editing

Pierre Sabatier: Investigation, Resources, Writing - Review \& Editing

Stéphane Marcotte: Resources, Writing - Review \& Editing

Edouard Patault: Writing - Review \& Editing

Quentin Faivre: Investigation

Florence Portet-Koltalo: Conceptualization, Investigation, Resources, Writing - Review \& Editing, Supervision 


\section{Declaration of interests}

$\bigotimes$ The authors declare that they have no known competing financial interests or personal relationships that could have appeared to influence the work reported in this paper.

$\square$ The authors declare the following financial interests/personal relationships which may be considered as potential competing interests: 
Figure 1. A. The Seine River Watershed; B. The Eure River Watershed; C. Study Area; D. Sediment core locations in the Les Damps Pond and current meter, turbidity probe and TIMS locations; E. Sediment core locations in the Martot Pond and F. Sediment core location in the La Forge Pond.

Figure 2. A. Flow $\left(\mathrm{m}^{3} \mathrm{~s}^{-1}\right)$ and SPM Flux $\left(\mathrm{x} 10^{4} \mathrm{t} \mathrm{month}^{-1}\right)$ at the Les Damps site; B. TMM concentrations (mg $\left.\mathrm{kg}^{-1}\right)$ at the Les Damps site.

Figure 3. A. Grain size distribution, $\mathrm{D}_{50}$ along the DAM15-02 core and TOC along the DAM17-02 core; B. Grain size distribution, $\mathrm{D}_{50}$ and TOC along the MAR15-01 core.

Figure 4. Age model for MAR15-01 core building with A. ${ }^{210} \mathrm{~Pb}_{\mathrm{ex}}$; B. ${ }^{137} \mathrm{Cs}$ and. ${ }^{241} \mathrm{Am}$ (the first identification of ${ }^{137} \mathrm{Cs}$ in 1955 (FF 1955), the maximum fallout from atmospheric nuclear weapon testing in 1963 (NWT 1963) and the Chernobyl accident in 1986 (C 1986) are represented); and C. Age model.

Figure 5. A. TMM concentrations along the MAR16-02 core; $\mathrm{B}$. Pb isotope ratios along the MAR15-01 core (the Seine Unit U2 is represented in grey).

Figure 6. TMM concentrations along the DAM17-02 core. Boxplot representing TMM concentrations from SPM.

Figure 7. Eure River inputs to the Seine estuary and estimation of Eure River contributions.

Figure 8. Three isotope diagrams ${ }^{208} \mathrm{~Pb} /{ }^{206} \mathrm{~Pb}$ versus ${ }^{206} \mathrm{~Pb} /{ }^{207} \mathrm{~Pb}$. 
Table 1. Characteristics of sediment cores collected in the La Forge Pond, the Les Damps Pond and the Martot Pond (WGS 84).

\begin{tabular}{cccccc}
\hline Pond & Core ID & IGSN & Longitude (X) & Latitude (Y) & Core Length (cm) \\
\hline \multirow{2}{*}{ LES DAMPS } & DAM15-02 & IEM2C0016 & $1^{\circ} 10^{\prime} 9.05^{\prime \prime} \mathrm{E}$ & $49^{\circ} 18^{\prime} 16.13^{\prime \prime} \mathrm{N}$ & 80 \\
& DAM17-02 & IEM2C000E & $1^{\circ} 10^{\prime} 13.26^{\prime \prime} \mathrm{E}$ & $49^{\circ} 18^{\prime} 15.66^{\prime \prime} \mathrm{N}$ & 90 \\
& MAR15-01 & IEM2C0001 & $1^{\circ} 03^{\prime} 1.68^{\prime \prime} \mathrm{E}$ & $49^{\circ} 17^{\prime} 49.68^{\prime \prime} \mathrm{N}$ & 138 \\
MARTOT & MAR16-02 & IEM2C0008 & $1^{\circ} 03^{\prime} 2.60^{\prime \prime} \mathrm{E}$ & $49^{\circ} 17^{\prime} 49.30^{\prime \prime} \mathrm{N}$ & 129 \\
& FOR17-02 & IEM2C001D & $0^{\circ} 37^{\prime} 47.89^{\prime \prime} \mathrm{E}$ & $48^{\circ} 37^{\prime} 51.75^{\prime \prime} \mathrm{N}$ & 69.5 \\
\hline
\end{tabular}


Table 2. Age (A.D.), $\mathrm{D}_{50}(\mu \mathrm{m})$, TOC (\%) and TMM $\left(\mathrm{mg} \mathrm{kg}^{-1}\right)$ at the bottom of the FOR17-02 core.

\begin{tabular}{ccccccccccccccc}
\hline AGE & $\mathrm{D}_{50}$ & $\mathrm{TOC}$ & $\mathrm{V}$ & $\mathrm{Cr}$ & $\mathrm{Co}$ & $\mathrm{Ni}$ & $\mathrm{Cu}$ & $\mathrm{Zn}$ & $\mathrm{As}$ & $\mathrm{Ag}$ & $\mathrm{Cd}$ & $\mathrm{Sb}$ & $\mathrm{Pb}$ & $\mathrm{Th}$ \\
\hline $1646-1669$ & 20.9 & 2.77 & 43.2 & 32.5 & 5.58 & 9.78 & 5.60 & 32.3 & 6.56 & 0.19 & 0.11 & 0.41 & 10.6 & 3.96 \\
\hline
\end{tabular}

Table 3. Flux of particulate TMM $\left(\mathrm{kg} \mathrm{month}^{-1}\right)$ at the Les Damps site.

\begin{tabular}{cccccccccccccc}
\hline Sampling Interval & $\mathbf{V}$ & $\mathbf{C r}$ & $\mathbf{M n}$ & $\mathbf{C o}$ & $\mathbf{N i}$ & $\mathbf{C u}$ & $\mathbf{Z n}$ & $\mathbf{A s}$ & $\mathbf{A g}$ & $\mathbf{C d}$ & $\mathbf{S b}$ & $\mathbf{P b}$ & $\mathbf{T h}$ \\
\hline 27-Jan-17-31-Jan-17 & 11.3 & 14.6 & 89.2 & 2.14 & 6.55 & 15.9 & 68.0 & 1.64 & 0.36 & 0.51 & 0.41 & 36.3 & 1.28 \\
Feb-17 & 300 & 389 & 2378 & 57.1 & 175 & 423 & 1812 & 43.8 & 9.73 & 13.6 & 11.0 & 967 & 34.1 \\
Mar-17 & 2065 & 2676 & 16359 & 393 & 1201 & 2908 & 12462 & 301 & 66.9 & 93.3 & 75.5 & 6651 & 235 \\
Apr-17 & 166 & 212 & 1307 & 33.4 & 106 & 204 & 980 & 25.5 & 3.58 & 6.60 & 5.71 & 523 & 18.8 \\
May-17 & 199 & 261 & 1830 & 41.3 & 135 & 240 & 1226 & 30.6 & 5.54 & 8.65 & 6.68 & 669 & 22.6 \\
Jun-17 & - & - & - & - & - & - & - & - & - & - & - & - & - \\
Jul-17 & 42.7 & 57.5 & 402 & 9.40 & 26.9 & 53.2 & 261 & 6.37 & 1.65 & 1.81 & 1.54 & 155 & 5.16 \\
Aug-17 & 484 & 651 & 4549 & 106 & 304 & 602 & 2957 & 72.2 & 18.6 & 20.4 & 17.5 & 1751 & 58.4 \\
Sep-17 & 497 & 704 & 5344 & 104 & 314 & 750 & 3214 & 67.5 & 16.2 & 24.8 & 19.2 & 1800 & 59.8
\end{tabular}




\begin{tabular}{cccccccccccccc} 
Oct-17 & 328 & 475 & 3634 & 68.8 & 208 & 504 & 2654 & 44.9 & 10.5 & 14.8 & 12.6 & 1190 & 39.0 \\
Nov-17 & 74.5 & 113 & 782 & 16.2 & 52.3 & 134 & 450 & 10.6 & 2.87 & 2.85 & 2.52 & 266 & 8.88 \\
Dec-17 & 843 & 1147 & 8165 & 167 & 519 & 1402 & 5437 & 120 & 20.7 & 40.6 & 30.1 & 2646 & 99.5 \\
\hline \hline ¿2017 & 5010 & 6701 & 44839 & 999 & 3047 & 7236 & 31521 & 724 & 157 & 228 & 183 & 16653 & 582 \\
\hline \hline Jan-18 & 10904 & 13155 & 90856 & 2028 & 5972 & 14137 & 58065 & 1637 & 187 & 398 & 336 & 26908 & 1267 \\
Feb-18 & 3757 & 4505 & 28591 & 698 & 2058 & 4926 & 19793 & 574 & 63.4 & 138 & 115 & 9138 & 436 \\
Mar-18 & 4332 & 5390 & 32852 & 801 & 2511 & 6568 & 24403 & 669 & 66.6 & 178 & 144 & 11131 & 495 \\
Apr-18 & 73.4 & 101 & 522 & 13.9 & 43.8 & 116 & 424 & 11.2 & 1.95 & 3.54 & 2.70 & 240 & 8.60 \\
01-May-18-22-May-18 & 304 & 419 & 2160 & 57.3 & 181 & 481 & 1755 & 46.2 & 8.08 & 14.7 & 11.2 & 992 & 35.6 \\
\hline
\end{tabular}


Table 4. TMM concentrations ( $\mathrm{mg} \mathrm{kg}^{-1}$ ) in the DAM17-02 core (ICP-MS).

\begin{tabular}{ccccccccccccc}
\hline Sampling Depth (cm) & $\mathbf{V}$ & $\mathbf{C r}$ & $\mathbf{C o}$ & $\mathbf{N i}$ & $\mathbf{C u}$ & $\mathbf{Z n}$ & $\mathbf{A s}$ & $\mathbf{A g}$ & $\mathbf{C d}$ & $\mathbf{S b}$ & $\mathbf{P b}$ & $\mathbf{T h}$ \\
\hline 1 & 38.0 & 54.4 & 7.26 & 24.8 & 67.1 & 300 & 5.81 & 1.23 & 3.34 & 1.81 & 268 & 4.88 \\
7 & 34.9 & 56.3 & 7.39 & 24.6 & 71.6 & 281 & 5.58 & 1.41 & 3.24 & 1.84 & 286 & 4.40 \\
25 & 44.8 & 61.5 & 8.73 & 32.2 & 90.2 & 305 & 7.13 & 2.13 & 3.61 & 5.82 & 833 & 5.09 \\
29 & 42.5 & 66.5 & 8.32 & 29.8 & 110 & 339 & 7.13 & 2.40 & 4.84 & 6.62 & 859 & 4.01 \\
49 & 46.6 & 211 & 15.5 & 81.6 & 377 & 956 & 9.31 & 4.16 & 49.6 & 1.84 & 171 & 5.51 \\
51 & 48.5 & 204 & 14.3 & 86.6 & 451 & 877 & 10.47 & 3.94 & 54.1 & 1.53 & 146 & 5.60 \\
53 & 49.7 & 186 & 15.0 & 95.5 & 560 & 849 & 11.54 & 3.72 & 56.9 & 1.33 & 133 & 5.71 \\
55 & 51.6 & 178 & 14.2 & 91.0 & 594 & 841 & 13.03 & 3.31 & 53.1 & 1.46 & 135 & 5.90 \\
61 & 48.2 & 178 & 10.7 & 68.9 & 523 & 821 & 11.54 & 3.22 & 44.2 & 1.51 & 161 & 5.68 \\
89 & 49.0 & 76.6 & 9.26 & 31.7 & 206 & 576 & 25.74 & 2.09 & 2.25 & 1.65 & 171 & 4.97 \\
\hline
\end{tabular}


Table 5. Enrichment Factor (EF) based on the reference level from the DAM17-02 core $\left(\mathrm{EF}_{\mathrm{DAM}}\right)$ and the geochemical background of the Eure River Watershed $\left(\mathrm{EF}_{\mathrm{FOR}}\right)$.

\begin{tabular}{|c|c|c|c|c|c|c|c|c|c|c|c|c|c|c|c|c|c|c|c|c|}
\hline \multirow[b]{2}{*}{ Depth $(\mathrm{cm})$} & \multicolumn{2}{|c|}{$\mathrm{Cr}$} & \multicolumn{2}{|c|}{ Co } & \multicolumn{2}{|c|}{$\mathrm{Ni}$} & \multicolumn{2}{|c|}{$\mathrm{Cu}$} & \multicolumn{2}{|c|}{$\mathbf{Z n}$} & \multicolumn{2}{|c|}{$\overline{\text { As }}$} & \multicolumn{2}{|c|}{$\overline{A g}$} & \multicolumn{2}{|c|}{ Cd } & \multicolumn{2}{|c|}{$\overline{S b}$} & \multicolumn{2}{|c|}{$\overline{P b}$} \\
\hline & $\overline{E F_{\text {DAM }}}$ & $\mathrm{EF}_{\mathrm{FOR}}$ & $\mathrm{EF}_{\mathrm{DAM}}$ & $\mathrm{EF}_{\mathrm{FOR}}$ & $\mathrm{EF}_{\mathrm{DAM}}$ & $\mathrm{EF}_{\mathrm{FOR}}$ & $\mathrm{EF}_{\mathrm{DAM}}$ & $\overline{\mathrm{EF}_{\mathrm{FOR}}}$ & $\mathrm{EF}_{\mathrm{DAM}}$ & $\mathrm{EF}_{\mathrm{FOR}}$ & $\mathrm{EF}_{\mathrm{DAM}}$ & $\mathrm{EF}_{\mathrm{FOR}}$ & $\mathrm{EF}_{\text {DAM }}$ & $\mathrm{EF}_{\mathrm{FOR}}$ & $\mathrm{EF}_{\text {DAM }}$ & $\mathrm{EF}_{\mathrm{FOR}}$ & $\mathrm{EF}_{\mathrm{DAM}}$ & $\mathrm{EF}_{\mathrm{FOR}}$ & $\mathrm{EF}_{\mathrm{DAM}}$ & $\overline{\mathrm{EF}_{\mathrm{FOR}}}$ \\
\hline 1 & 1.0 & 1.4 & 1.00 & 1.1 & 1.0 & 2.1 & 1.0 & 9.7 & 1.0 & 7.5 & 1.0 & 0.7 & 1.0 & 5.2 & 1.5 & 24 & 1.1 & 3.6 & 1.6 & 21 \\
\hline 7 & 1.1 & 1.6 & 1.1 & 1.2 & 1.1 & 2.3 & 1.2 & 12 & 1.0 & 7.8 & 1.1 & 0.8 & 1.3 & 6.6 & 1.6 & 26 & 1.3 & 4.0 & 1.9 & 24 \\
\hline 25 & 1.1 & 1.5 & 1.2 & 1.2 & 1.2 & 2.6 & 1.3 & 13 & 1.0 & 7.3 & 1.2 & 0.8 & 1.7 & 8.7 & 1.6 & 25 & 3.4 & 11 & 4.7 & 61 \\
\hline 29 & 1.5 & 2.0 & 1.4 & 1.5 & 1.5 & 3.0 & 2.0 & 20 & 1.4 & 10 & 1.5 & 1.1 & 2.4 & 12 & 2.7 & 42 & 5.0 & 16 & 6.2 & 80 \\
\hline 49 & 3.4 & 4.7 & 1.9 & 2.0 & 2.9 & 6.0 & 5.0 & 48 & 2.8 & 21 & 1.4 & 1.0 & 3.0 & 16 & 20 & 313 & 1.0 & 3.2 & 0.9 & 12 \\
\hline 51 & 3.3 & 4.4 & 1.7 & 1.8 & 3.0 & 6.3 & 5.9 & 57 & 2.5 & 19 & 1.6 & 1.1 & 2.8 & 15 & 21 & 336 & 0.8 & 2.6 & 0.8 & 10 \\
\hline 53 & 2.9 & 4.0 & 1.8 & 1.9 & 3.3 & 6.8 & 7.1 & 69 & 2.4 & 18 & 1.7 & 1.2 & 2.6 & 14 & 22 & 346 & 0.7 & 2.2 & 0.7 & 8.7 \\
\hline 55 & 2.7 & 3.7 & 1.6 & 1.7 & 3.0 & 6.2 & 7.3 & 71 & 2.3 & 17 & 1.9 & 1.3 & 2.2 & 12 & 20 & 312 & 0.7 & 2.4 & 0.7 & 8.6 \\
\hline 61 & 2.8 & 3.8 & 1.3 & 1.3 & 2.4 & 4.9 & 6.7 & 65 & 2.3 & 18 & 1.7 & 1.2 & 2.2 & 12 & 17 & 270 & 0.8 & 2.6 & 0.8 & 11 \\
\hline 89 & 1.4 & 1.9 & 1.3 & 1.3 & 1.3 & 2.6 & 3.0 & 29 & 1.9 & 14 & 4.4 & 3.1 & 1.7 & 9 & 1.0 & 16 & 1.0 & 3.2 & 1.0 & 13 \\
\hline
\end{tabular}




\section{HIGHLIGHTS:}

- We assess and characterise the anthropogenic impacts occurring in the Eure River.

- Current particulate TMM concentrations and flux were estimated using TIMS.

- Temporal trends of TMM were reconstructed using sediment cores.

- A permanent anthropogenic baseline due to industrial contamination was highlighted.

- The origin of the $\mathrm{Pb}$ contamination can be traced using $\mathrm{Pb}$ isotopes. 

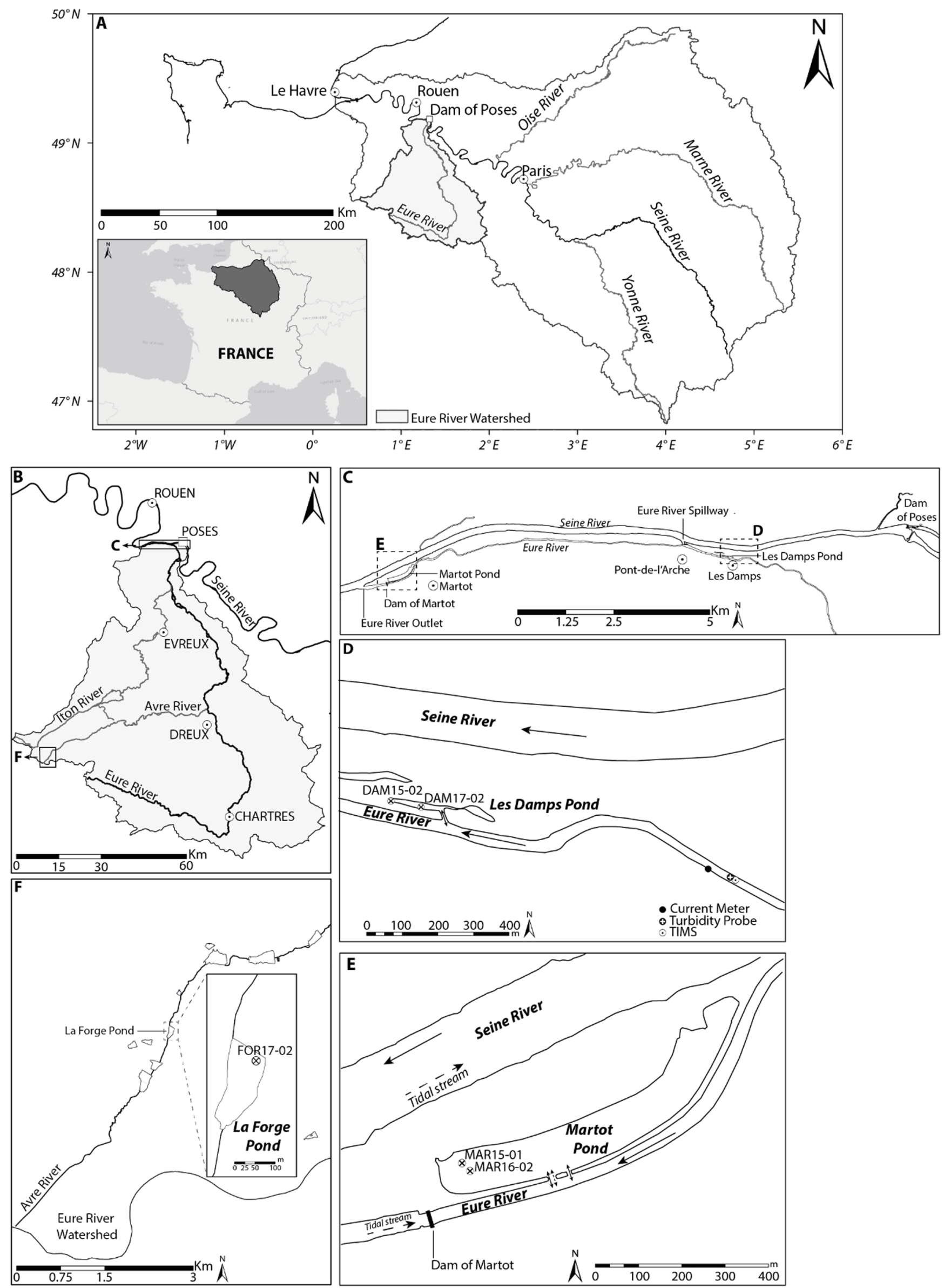
A

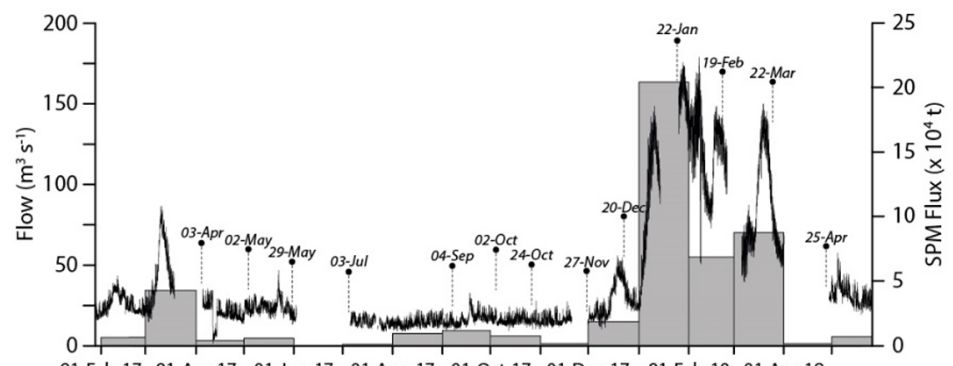

B

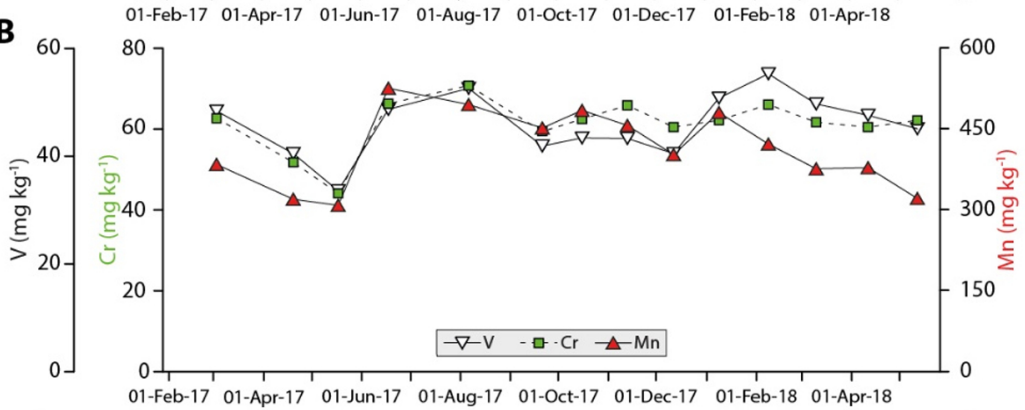

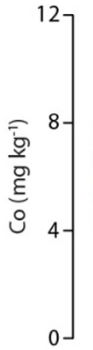

01-Feb-17 01-Apr-17 01-Jun-17 01-Aug-17 01-Oct-17 01-Dec-17 01-Feb-18 01-Apr-18

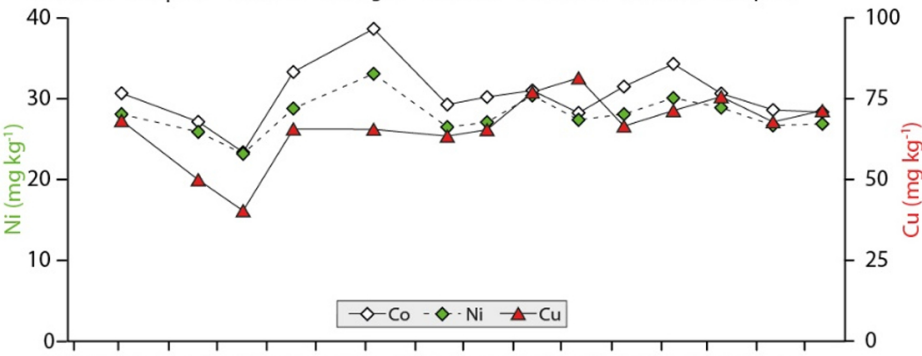

01-Feb-17 01-Apr-17 01-Jun-17 01-Aug-17 01-Oct-17 01-Dec-17 01-Feb-18 01-Apr-18
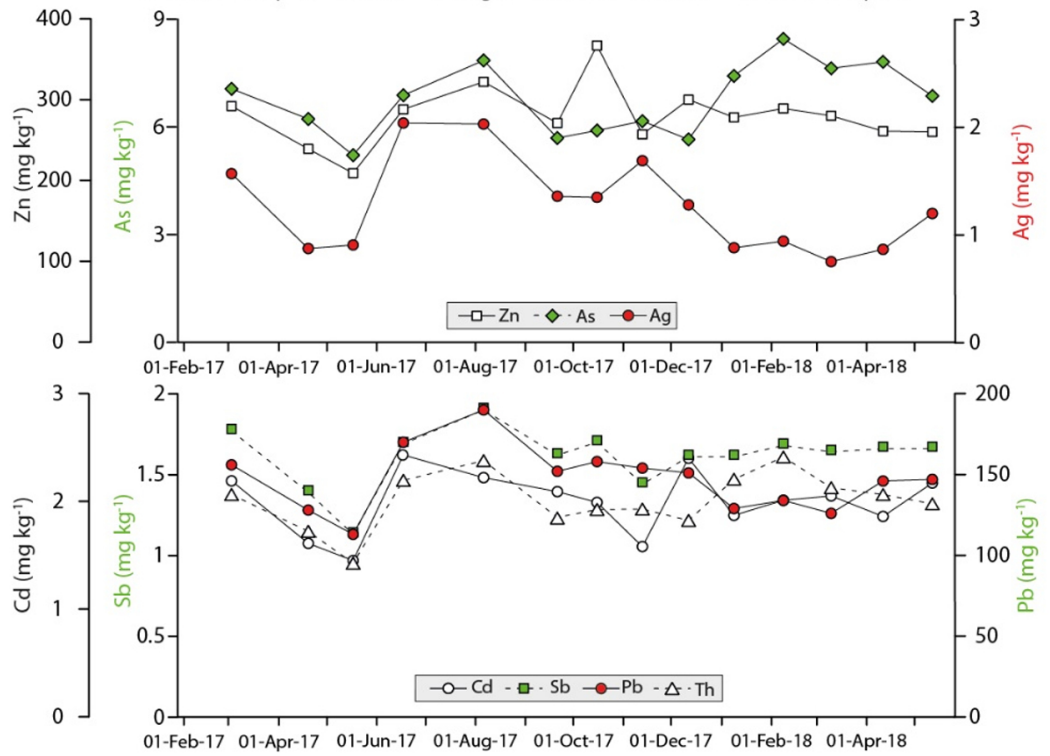

$\Gamma^{8}$ 


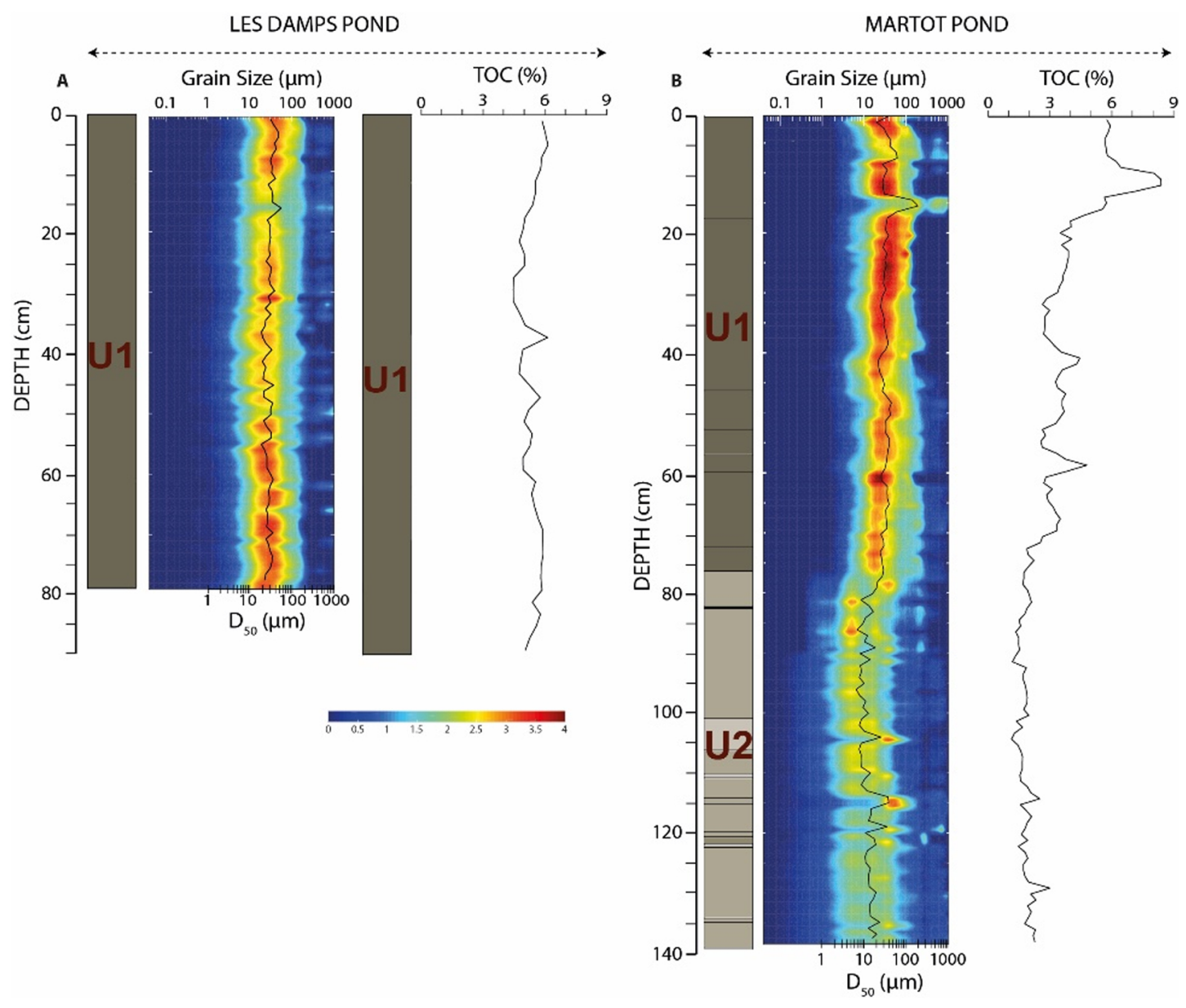

Figure 3 


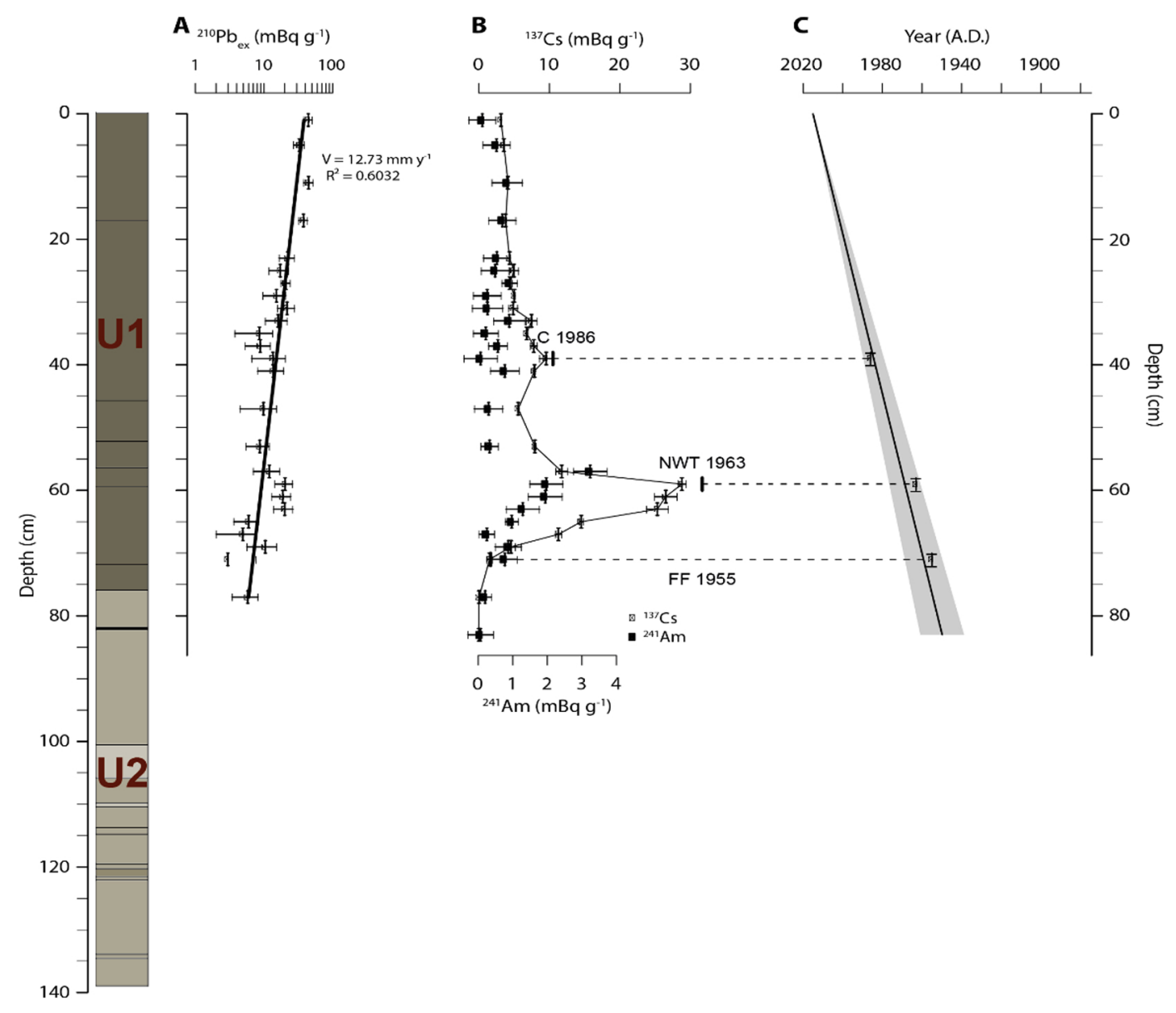

Figure 4 


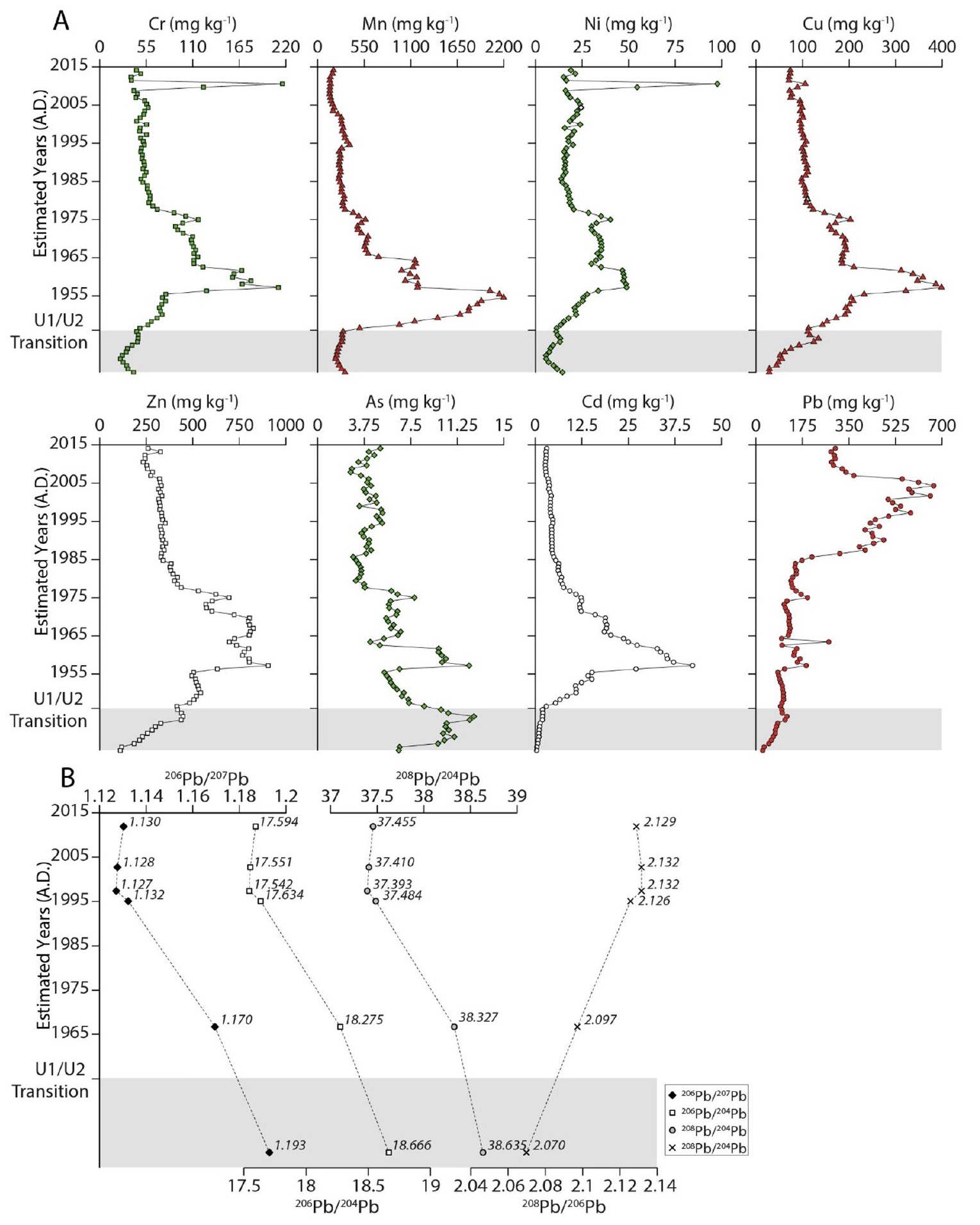

Figure 5 

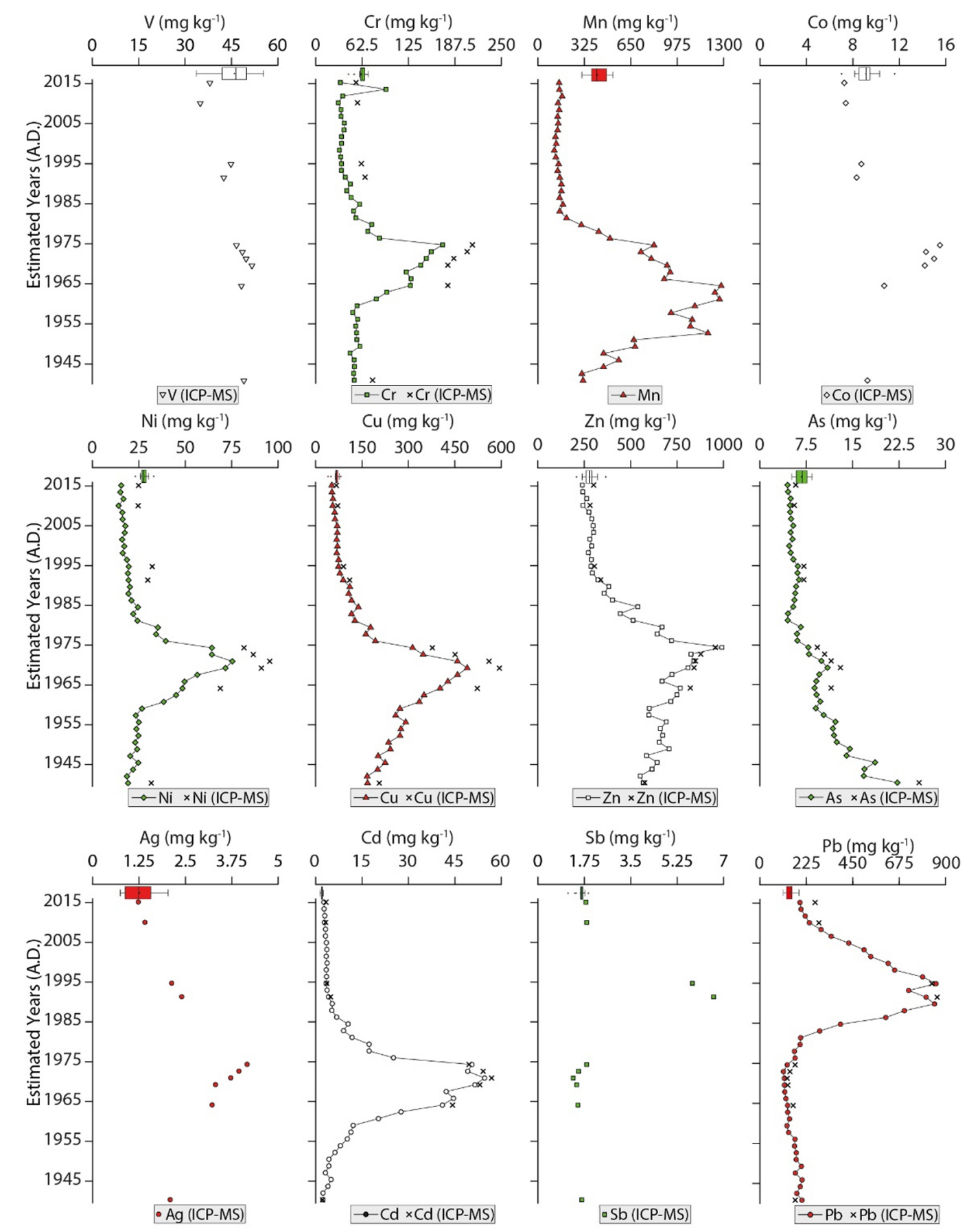

Th ( $\mathrm{mg} \mathrm{kg}^{-1}$ )

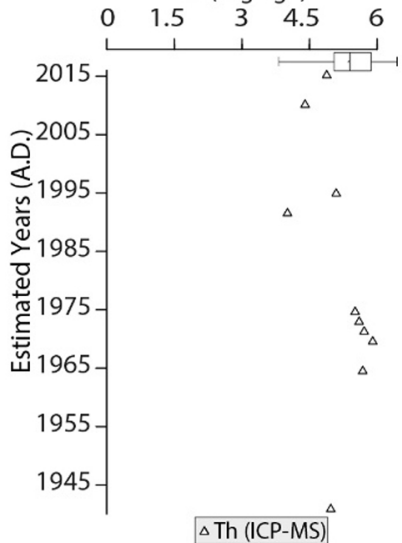

$\triangle$ Th (ICP-MS) 
Seine River inputs (1994 -2003)

(Thévenot et al., 2007)

- Cr:87ty ${ }^{-1}$

- Cu: 84 ty $^{-1}$

$-\mathrm{Zn}: 315 t^{-1}$

$-C d: 1.75 t y^{-1}$

- $\mathrm{Pb}: 88$ ty $^{-1}$ Poses

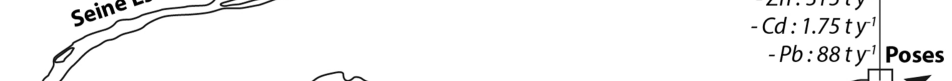

Current contributions from Eure River

- $\mathrm{Cr}: 7 \%$

- Cu: $8 \%$

- Zn: $9 \%$

- Cd: $10 \%$

- $P b: 16 \%$

Theorical past inputs (1992-1996)

\section{Les Damps}

Martot Eure River inputs (2017) (Table 3)

- Cr:6.7ty

- Cu: $7.2 t^{-1}$

- Zn:31.5 ty $y^{-1}$

- Cd: $0.2 t y^{1}$

- $P b: 16.6 t y^{\prime}$

$-P b: 95 t y^{\prime}$

Past contributions (1992-1996)

- $\mathrm{Pb}: 52 \%$

Figure 7 


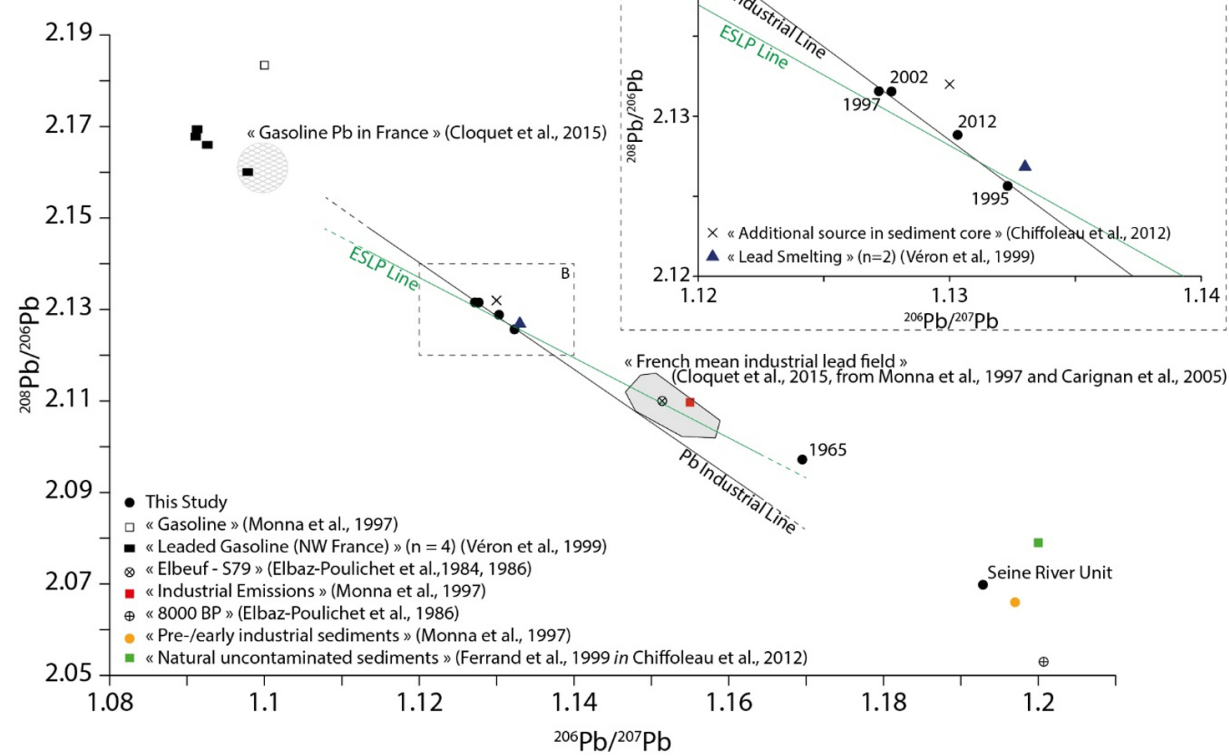

Figure 8 